\title{
Managing Tallgrass Prairies for Productivity and Ecological Function: A Long-Term Grazing Experiment in the Southern Great Plains, USA
}

\author{
Jean L. Steiner $\left.{ }^{1}{ }^{(}\right)$, Patrick J. Starks ${ }^{2, *}$, James P.S. Neel ${ }^{2}$, Brian Northup ${ }^{2}$, Kenneth E. Turner ${ }^{2}{ }^{(\mathbb{C}}$, \\ Prasanna Gowda ${ }^{3}$, Sam Coleman ${ }^{4}$ and Michael Brown ${ }^{2}$ \\ 1 United States Department of Agriculture-Agricultural Research Service, Kansas State University, Manhattan, \\ KS 66502, USA; jlsteiner@ksu.edu \\ 2 United States Department of Agriculture-Agricultural Research Service, El Reno, OK 73036, USA; \\ Jim.neel@usda.gov (J.P.S.N.); Brian.northup@usda.gov (B.N.); Ken.turner@usda.gov (K.E.T.); \\ michaelbrown@atlinkwifi.com (M.B.) \\ 3 United States Department of Agriculture-Agricultural Research Service, Stoneville, MS 38776, USA; \\ Prasanna.gowda@usda.gov \\ 4 United States Department of Agriculture-Agricultural Research Service, Azle, TX 76020, USA; \\ colespec@gmail.com \\ * Correspondence: Patrick.starks@usda.gov; Tel.: +1-405-262-5291
}

Received: 3 July 2019; Accepted: 28 October 2019; Published: 30 October 2019

\begin{abstract}
The Great Plains of the USA is one of largest expanses of prairie ecosystems in the world. Prairies have been extensively converted to other land uses. The remaining prairie ecosystems are important for livestock grazing and provide benefits including habitat for avian, terrestrial, and aquatic species, carbon regulation, and hydrologic function. While producers, land management agencies, and some researchers have promoted livestock management using rotational stocking for increased production efficiency and enhanced ecosystem function, scientific literature has not provided a consensus on whether rotational stocking results in increased plant biomass or animal productivity. To address this research need, we established long-term grazing research using an adaptive management framework to encompass a wide range of production and ecological interactions on native grassland pastures. This paper describes objectives, design, and implementation of the long-term study to evaluate productivity and ecological effects of beef cow-calf management and production under continuous system (CS) or rotational system (RS) on native tallgrass prairie. Findings from 2009 to 2015 indicate that plant biomass and animal productivity were similar in the two grazing management systems. There were some indicators that forage nutritive value of standing biomass and soil nutrient content were enhanced in the RS system compared with the CS, yet individual calf body weight (BW) at weaning was greater in the CS. This prepares us to engage with producers to help determine the focus for the next phase of the research.
\end{abstract}

Keywords: long-term agroecosystem research network; LTAR; rotational grazing

\section{Introduction}

Efficiency of forage use in livestock production systems is important for global food security. Pastures, rangeland, and forest lands suited to grazing ruminant livestock constitute $35 \%$ of the U.S. land area [1]. Pastures and rangelands are a dominant land use and support ruminant production in every climatic regime on every continent [2]. In 2000, about 35 million $\mathrm{km}^{2}$ were in permanent pasture, representing $30 \%$ of the world's land area and over $70 \%$ of the agricultural area [3]. Animal meat and dairy products are a critical component of human food systems, including in some of the 
least food-secure regions of the world. It has been estimated [4] that 1 billion people depend on livestock for income and food security, including $70 \%$ of the world's 880 million rural-poor populations. It has been suggested [5] that as protein and micronutrient concentrations of grain crops decline with increasing atmospheric carbon dioxide $\left(\mathrm{CO}_{2}\right)$ concentrations, an additional 122 million people could struggle with protein-deficient diets, 175 million people would experience zinc-deficient diets, and 1.4 million women of child-bearing age and children under 5 could face a $20 \%$ increase in occurrence of anemia. These estimates are based on the 2050 projections for human population and atmospheric $\mathrm{CO}_{2}$ concentration. Food security challenges and biodiversity conservation must be addressed as a linked process [6] based on increasing productivity while enhancing biodiversity and other ecosystem services from existing agricultural lands, particularly in the face of changing climate. [7,8]. Understanding interactions between climate variability and agricultural systems is essential to ensure a sustainable food supply while maintaining agricultural soil and water resources for the next generation $[9,10]$.

Pasture systems around the world are heterogeneous, ranging from those dominated by native vegetation, such as in the central portion of North America, Argentina, and parts of Asia, to those that are dominated by domesticated pasture, such as in Europe, New Zealand, eastern North America, and parts of Asia [11]. The native vegetation can range from relatively intact ecosystems to vegetation that may have regrown on abandoned cropland. Grasslands face numerous challenges, some long-standing and others of growing importance. As human populations have expanded, lands that were formerly grassland have been converted to urban and cropland or fragmented into smaller holdings. In general, remaining grasslands are located on drier, steeper, or less fertile areas in every region of the world.

Prairies, particularly tallgrass prairies, have been extensively converted to other land uses. However, the Great Plains of the USA remains one of largest expanses of prairie ecosystems in the world [12-14]. These remaining prairie ecosystems are important for livestock grazing and provide numerous benefits of diverse habitat for avian, terrestrial, and aquatic species [15-17], carbon regulation [18,19], and hydrologic function [20,21]. The Northern Great Plains has exhibited cooling and wetting over recent decades, while the Southern Great Plains (SGP) has exhibited increased aridity [19]. Challenges to these critical ecosystems in the SGP include encroachment by woody species [22-25], increased aridity and drought [19,26], climate change [27], and fragmentation of the landscape [28]. Additional resource concerns include low-productivity land and unstable stream networks. To address complex, interactive challenges such as these, an interdisciplinary systems research approach is needed [29].

Synthesis of a large body of literature indicated stocking rate to be the key management decision [30]. Low to moderate stocking rates provided the optimal vegetation required for livestock and wildlife productivity and the best economic returns. High-intensity, rotational stocking was advanced in the 1960s to improve forage harvest efficiency, increase livestock-carrying capacity, and boost economic returns [31]. Adoption of conservation cropping and adaptive multi-paddock grazing management was proposed to reduce the carbon footprint of agriculture in North America and promote a wide range of ecosystem services from agricultural lands [32]. However, a review of number of grazing studies found no plant or animal production benefit to rotational stocking compared with continuous stocking [33]. Subsequently, [34] recommended a research framework that would incorporate human elements such as goal setting, experiential knowledge, and decision making along with ecological variables and an adaptive framework for managing rangelands systems. Published studies of grazing systems indicated that grazed grasslands accumulated soil organic carbon (SOC) at a faster rate than undefoliated grasslands and that low to moderate livestock stocking rates favored SOC accumulation compared with high stocking rates [7]. Additionally it was found that more digestible forages defoliated at optimal maturity may decrease methane emissions by grazing ruminants. However, the effects of methods of applying grazing pressure on the $C$ balance of grasslands have been mixed, particularly as stocking methods have regularly been shown to have little effect on productivity of grasslands at moderate stocking rates [35-41]. 
Adaptive management of grazing systems may incorporate periods of intensive grazing in a rotational framework, but with a focus on goal setting, monitoring, and adaptive response to conditions in the field. Some ranchers in the SGP have reported improved rangeland health and increased productivity and/or profitability after adopting holistic, rotational, or intensively managed grazing systems, but relatively little research focuses on these types of systems. To address this research need, we established long-term grazing research within an adaptive management framework to encompass a wide range of production and ecological interactions on native grassland pastures, specifically to evaluate productivity and ecological effects of beef cow-calf management and production under continuous and rotational stocking systems on native tallgrass prairie. The purpose of this paper is to describe the objectives, design, and implementation of the long-term study and present productivity indicators from 2009 to 2015. Additional papers in this issue present findings related to plant and soil responses to grazing management systems.

\section{Stakeholder Engagement}

The need for research was identified in collaboration with ranchers from the Oklahoma Grazing Lands Conservation Association. In spring of 2008, a workshop was convened at the United States Department of Agriculture (USDA) Agricultural Research Service (ARS), Grazinglands Research Laboratory, El Reno, OK, USA to identify producer concerns and priorities and identify research needed to develop the information requested. The producers were interested in research on continuous versus rotational stocking management, and, in particular, the impacts of high-stocking-rate, short-duration rotations. They recommended that the number of animals available be concentrated into herds that are managed to balance grazing periods with forage recovery periods to keep the forage in the rotational system physiologically "young". For the continuous stocking system, the producers identified winter management as an important factor impacting the next growing season. The producers recommended that fall- and winter-dormant forage be rationed (limited grazed) but grazed down prior to onset of spring growth to create litter and open the canopy to sunlight. The goal was to use adaptive management to optimize productivity and ecosystem performance for each management system. Responses that producers and researchers identified were grazing system effects on plant vegetative community and soil biology, as well as overall beef production and profitability. Approximately 250-300 ha of land was identified to support the experiment. After discussion, the research group determined that continuous stocking (CS) and rotational stocking (RS) management treatments would be established, with an embedded experiment that included exclosures for ungrazed (UG) land treatments and for high-stocking-density, short-duration (HDSD) grazing treatments. Results from the HDSD treatments are not reported in this paper but are reported by Northup et al. [42,43], and those from the UG plots are reported by Starks et al. [44].

\section{Research Questions}

In 2013, this experiment was incorporated into the Long-Term Agroecosystems Research (LTAR) Common Experiment $[45,46]$. The LTAR Common Experiment was established at 18 sites across the U.S., with each site implementing research with two treatments, Business as Usual (BAU, in this case CS) or Aspirational (ASP, in this case adaptive, RS). Research teams at each site and across sites focused on sustainability from the perspective of production, environment, and social or cultural responses. Table 1 summarizes research questions, based on input from the 2008 producer workshop, articulated into the LTAR framework of linked ecosystem services and metrics used to quantify the system effects on sustainability. 
Table 1. Research questions and metrics to address ecosystem services of alternate grazing systems.

\begin{tabular}{|c|c|c|c|}
\hline Sustainability Pillars & Ecosystem Services & Research Questions & Metrics \\
\hline Production & $\begin{array}{l}\text { Primary production } \\
\text { Secondary production }\end{array}$ & $\begin{array}{l}\text { How does grazing } \\
\text { management system } \\
\text { affect gross primary } \\
\text { production? Is animal } \\
\text { performance impacted } \\
\text { by management system? } \\
\text { How do management } \\
\text { system and climate } \\
\text { interact in controlling } \\
\text { productivity? }\end{array}$ & $\begin{array}{l}\text { Biomass production } \\
\text { Forage nutritive value } \\
\text { Breeding efficiency } \\
\text { Weaning weights per } \\
\text { unit area } \\
\text { Drought indices }\end{array}$ \\
\hline Environment & $\begin{array}{l}\text { Climate regulation } \\
\text { Soil nutrient cycling } \\
\text { Soil biodiversity } \\
\text { Plant biodiversity }\end{array}$ & $\begin{array}{l}\text { How does management } \\
\text { system affect plant and } \\
\text { soil biodiversity, soil } \\
\text { carbon and nutrients? }\end{array}$ & $\begin{array}{l}\text { Soil nutrient budgets: C, } \\
\text { N, macronutrients } \\
\text { Soil organic matter } \\
\text { (Phospholipid Fatty Acid } \\
\text { analysis-future) }\end{array}$ \\
\hline
\end{tabular}

Grazed tallgrass prairies also provide considerable social and cultural services, which are generally realized at landscape, watershed, and regional scales. While no research questions were developed around these ecosystem services in this field-scale experiment, the research site has provided education benefits through graduate and postdoctoral research projects. Additionally, on a regional scale, such land uses provide supporting services such as wildlife habitat and watershed function and extensive recreational services including hunting and birding.

\section{Site Description}

The USDA Agricultural Research Service, Grazinglands Research Laboratory is located in El Reno, Oklahoma ( $35^{\circ} 33^{\prime} 29^{\prime \prime} \mathrm{N}, 98^{\circ} 1^{\prime} 50^{\prime \prime} \mathrm{W}, 414 \mathrm{~m}$ above mean sea level). The laboratory is located on $2700 \mathrm{ha}$ of land, of which approximately 1200 ha are tallgrass prairie, most of which have been grazed at low stocking rates (animal unit (AU) ha ${ }^{-1}$ ) over the past several decades. In addition, a prescription of spring burns had been applied on a 3-5 year interval to limit invasion by woody species. However, after implementation of the study in 2009, the paddocks included in the study have experienced no burns of any kind.

\subsection{Climate}

The SGP has pronounced seasonal, year-to-year, and multi-year variations in air temperature and precipitation [47,48], which are key drivers of ecological processes and agricultural production [49]. Average annual minimum air temperature over the study region is about $9.2^{\circ} \mathrm{C}$. Typically, July and August are the warmest months of the year, while the coolest months coincide with the driest months of December, January, and February (mean $-2.3{ }^{\circ} \mathrm{C}$ ). Average monthly temperature peaks in July at $28^{\circ} \mathrm{C}$. Average annual precipitation over Central Oklahoma, USA is about $870 \mathrm{~mm}$. The "wet" season is generally the months of April through June (spring). On average, the spring months receive approximately $326 \mathrm{~mm}$ of rainfall or $38 \%$ of the annual precipitation. The "dry" season occurs in the winter months of December, January, and February. These months contribute about $13 \%$ to the annual precipitation, with an average seasonal precipitation of $111 \mathrm{~mm}$. Long-term monthly mean precipitation and temperature for 1994-2018 (period of record at the site) are shown in Figure 1. 


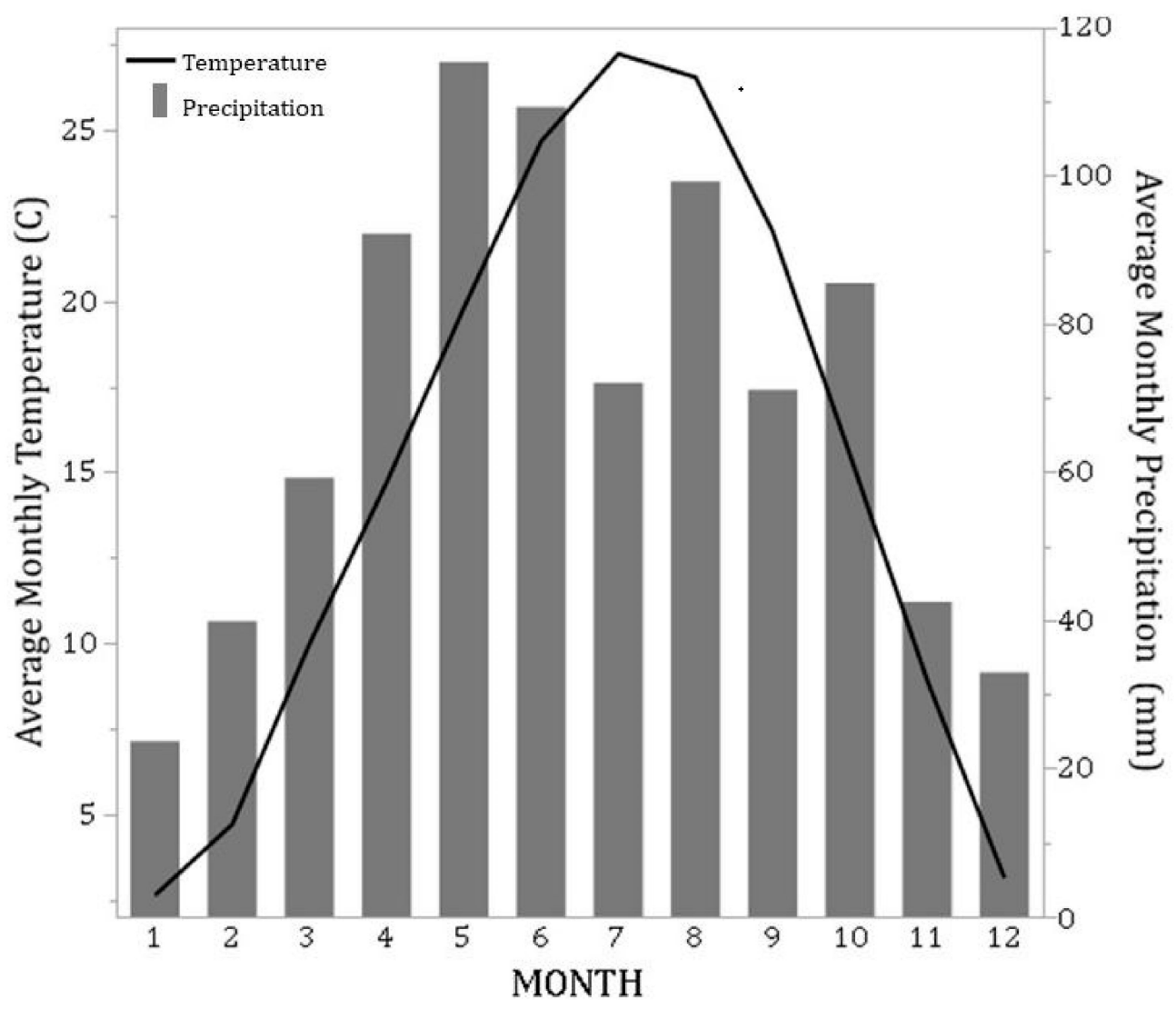

Figure 1. Monthly mean temperature precipitation for the El Reno site of the Oklahoma Mesonet, 1994-2018. Month 1 = January ... Month 12 = December. Data Source: Oklahoma Climate Survey, http://climate.ok.gov.

The average monthly soil volumetric water content $(\theta \mathrm{v})$ for the $0-100 \mathrm{~cm}$ layer indicates the strong intra- and interannual variability in the moisture regime (Appendix A Figure A1, methods in Appendix A.2). The general pattern is that the soil recharges with moisture in autumn, winter, and spring during the cool months and is depleted during the hot summer growing season. The 2011 and 2012 time periods experienced the driest summer conditions (June-August), with the difference being that 2012 entered the summer growing season with high soil water storage due to a wet autumn and winter and spring. Values for the 5, 10, 20, 50, and $100 \mathrm{~cm}$ layers are shown in Figures A2-A6.

The SGP experienced a persistent pluvial period lasting most of the last quarter of the 20th century [47], with a return to drier conditions in the early 21st century. Since 1990, extreme precipitation events have increased [50]. An increased frequency of dipole events-wet years following drought years was reported by [51]. The dipole events in the SGP can be extremely damaging as intense precipitation acts on depleted soil and vegetative surfaces, resulting in runoff, erosion, and flooding risks. Additionally, a high frequency of severe storms [52] with hail, extreme winds, and tornados can produce catastrophic losses to agricultural crops, livestock, and agricultural infrastructure. The variable and changing climate makes long-term research essential in order to determine interactive impacts of climate and management on a broad range of production and ecosystem responses.

\subsection{Soils and Vegetation}

The site is located in the Central Great Plains ecoregion [53], with dominant grass species being big bluestem (Andropogon gerardii), little bluestem (Schizachyrium scoparium), and Indiangrass (Sorghastrum nutans). The soils included the Norge silt loam (fine-silty, mixed, active, thermic Udic Paleustolls), Pond Creek silt loam (fine-silt, mixed, superactive, thermic Pachic Argiustolls), Kirkland-Pawhuska 
complex (fine, mixed, superactive, thermic Udertic Paleustolls), and Bethany silt loam (fine, mixed, superactive, thermic Pachic Paleustolls).

Analysis of particle sizes of soils in the study area (see methods below) showed the texture of the 0-30 cm layer was statistically similar in all field replicates and that there were no significant differences in $\mathrm{pH}$ or electrical conductivity (EC) (Table A1). The sand and clay fractions each accounted for $21 \%$ to $26 \%$ of the soil in each field replicate, and $\mathrm{pH}$ and EC were about 6 in all replicates.

\subsection{Layout and Experimental Design}

We established two replicates of two grazing systems on native tallgrass prairie, each with a dedicated herd of beef cattle (Figure 2). Two of the herds are managed using CS on assigned paddocks, and two herds are managed using RS management assigned to two groups of 10 sub-paddocks under an adaptive rotational grazing framework. Land area and initial animal information for each replicate in 2009 are given in Table 2. Cow numbers for each herd were based on an animal cow/calf unit $(500 \mathrm{~kg}$ cow body weight (BW)) and a targeted stocking rate of $\sim 3$ ha per cow/calf unit. Bodyweight of cows was measured at the time of weaning in 2009 to determine stocking rate for each replicate. Calves remain with the cows from March through weaning in October. Bulls are present with each cow herd during the June 1 to July 31 breeding season. The 10 sub-paddocks in the RS treatments ranged from 4.3 to 9.5 ha in RSa and from 5.3 to 12.9 ha in RSb.

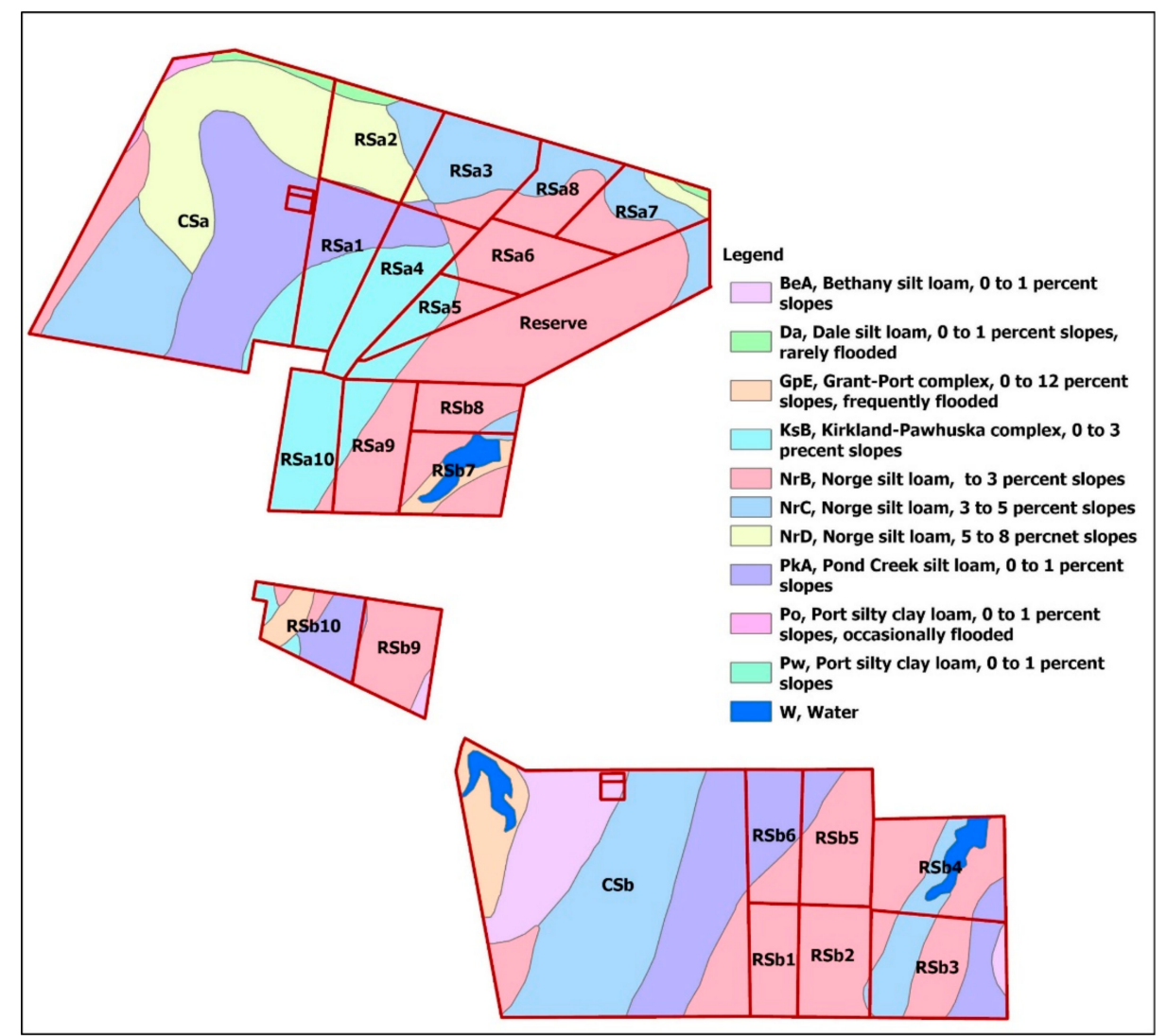

Figure 2. Map of research site at the USDA-ARS Grazinglands Research Laboratory, showing continuous (CSa, CSb) and rotational (RSa, RSb) locations on the USDA Natural Resources Conservation Service soils map. White boxes indicate exclosures for embedded high-density, short-duration grazing treatments described in Appendix A. 
Table 2. Paddock size, cow numbers, average cow bodyweight, cow animal unit (AU), and stocking rate (500 kg per AU) for 2009.

\begin{tabular}{ccccc}
\hline Treatment \& replicate & Area & Cows & Cow Bodyweight & Stocking Rate \\
\hline & ha & $\#$ & Kg & Cow AU ha $\mathbf{~}^{\mathbf{1}}$ \\
\hline Continuous-CSa & 58.6 & 20 & 614 & 0.42 \\
Continuous-CSb & 62.7 & 21 & 613 & 0.41 \\
Rotational-RSa & 78.1 & 25 & 584 & 0.37 \\
Rotational-RSb & 82.8 & 25 & 584 & 0.35 \\
\hline
\end{tabular}

\section{Materials and Methods}

\subsection{Soil Parameters}

In 2009, 40 soil sampling sites were located within each field replicate using a stratified sampling design, where the strata were composed of the soil mapping units in the area (downloaded from the USDA Natural Resources Conservation Service (NRCS) Geospatial Data Gateway-https://datagateway. nrcs.usda.gov/GDGOrder.aspx). The number of soil samples for a given strata within a field replicate was based upon an area-weighted average of the soil mapping units. Thus, if 50\%, 30\%, and $20 \%$ of a field replicate was underlain by soil mapping units X, Y, and Z, then map unit X would be assigned 20 sampling sites, whereas $Y$ would be assigned 12 and $Z$ eight. Sampling points within a given strata were randomly located and their positions recorded by a hand-held GPS device. Soil sampling in subsequent years was guided by these GPS coordinates.

Soil cores were extracted using a Giddings (Windsor, CO, USA) probe equipped with a $30 \mathrm{~cm}$ long barrel, having an inside diameter of $4 \mathrm{~cm}$ (nominally). Soil cores down to $60 \mathrm{~cm}$ were collected in 2009, from which bulk density $\left(\rho_{\mathrm{b}}\right)$ and particle fractions of sand, silt, and clay were determined for the 0-6, 6-12, 12-20, 20-30, and 30-60 cm intervals at all sampling locations. Bulk density was determined from the oven-dry soil weights and sampling volume, and particle size fractions were determined using the hydrometer method [54]. In 2012 and 2017, $\rho_{b}$ was measured in the 0-15 and 15-30 cm intervals. Thus for 2009, the 0-6 and 6-12 cm layer $\rho_{b}$ values were averaged to represent the 0-15 cm layer, and the 12-20 and 23-30 data were averaged to represent the 15-30 cm layer.

Particle size fractions, EC, and pH were determined only from the 2009 soil core data. The EC and $\mathrm{pH}$ were measured using a VWR Scientific conductivity meter (Control Company, Friendship, TX, USA). Additional methods for soil measurement and analysis are given in references $[42,43,55]$.

\subsection{Forage Biomass and Nutritive Parameters}

Two and five exclosures measuring $1.07 \mathrm{~m} \times 6.4 \mathrm{~m}$ were randomly located within the CS and RS replicates, respectively, for the purpose of measuring end-of-year biomass. The vegetative biomass in these exclosures was clipped to a height of $\approx 1 \mathrm{~cm}$ above the soil surface using a sickle bar mower and then weighed fresh. A grab sample was collected for determination of dry (forced-air oven, $65 \mathrm{C}$ ) biomass on a $\mathrm{kg} \mathrm{ha}^{-1}$ basis for each paddock.

In addition to the end-of-year biomass samples from exclosures, forage biomass and nutritive values were measured during the season. The CS paddocks were sampled from four to 11 times, depending upon year. Both CS replicates were sampled at least once a month from June through August. The biomass in the RS sub-paddocks was sampled prior to the introduction of cattle (three to four times per year, depending upon year). Samples were collected by clipping all standing vegetation within a $0.5 \mathrm{~m}^{2}$ sampling frame to within $1 \mathrm{~cm}$ of the soil surface and determining dry mass as indicated above. Four random forage subsamples per replicate were collected for each sample date.

Aliquots of oven-dried forage subsamples were ground, packed into sample cuvettes, and scanned on a benchtop near-infrared spectrometer (NIRS; Foss-NIR Systems, Silver Spring, MD, USA). The NIRS scans were analyzed in WinISI 1.5 (FOSS North America, Eden Prairie, MN, USA) for the purpose of identifying a representative subset of forage samples for wet chemistry determinations of total nitrogen 
$(\mathrm{N})$, acid detergent fiber (ADF), neutral detergent fiber (NDF), and in vitro true digestibility (IVTD). Analysis for ADF, NDF, and IVTD followed the procedures outlined by Ankom Technology (Macedon, NY, USA; https://www.ankom.com/analytical-methods-support/fiber-analyzer-a2000). Total N was determined through combustion analysis (Elementar Americas, Inc., Mt. Laurel, NJ, USA). The laboratory-measured values were then used in conjunction with the NIRS scans to develop and validate calibration equations to predict total N, ADF, NDF, and IVTD. Once satisfactorily calibrated and validated, the calibration equations were applied to the NIRS scans of the remaining forage samples to predict total N, ADF, NDF, and IVTD. Additional methods and analysis for plant data are detailed in reference [44].

\subsection{Animal Parameters}

The cows utilized for experimental purposes were Angus-cross cows with Brahman influence. These cows were bred to terminal sires to maximize heterosis (i.e., sire breed was not represented within the cow). Cows were bred to calve in the spring, and generally calved between mid-March and mid-May. Calves were typically weaned from the cows in October. At weaning, individual cow and calf weights were taken, as well as cow body condition score (BCS). The BCS score was based on a 1-9 scoring system, with a score of 5-6 being desirable, 1-4 being too thin, and 7-9 being overly fat. During the course of the year, each herd had ad libitium access to fresh water and a commercially available mineral. During the fall through spring seasons, all dry cows were supplemented with a $40 \%$ crude protein cattle cube to meet production-stage nutritional requirements. Cows were supplemented with a $20 \%$ crude protein, high-energy cube to meet production-stage nutritional requirements during early spring, after calving. Within the RS treatment, herds were moved to the next paddock in the rotation (sub-paddocks 1 through 10 ) when available forage biomass was reduced to approximately $50 \%$ of that available upon start of grazing, determined by visual examination of pastures by trained personnel. Cattle were not supplemented with conserved forage (hay) except during periods of snow or ice cover (at this research location, the snow or ice cover does not occur frequently nor persist for long periods). In those instances, cattle within each system were offered native hay at the rate of approximately $30 \mathrm{~kg}$ dry matter $(\mathrm{DM})$ per head per day until snow or ice cover had cleared.

All applicable national and/or institutional guidelines for the care and use of cattle were followed. Cattle were cared for in accordance with the standards of the Guide for the Care and Use of Agricultural Animals in Agricultural Research and Teaching [56]. Care of cows and calves grazing pastures followed approved standard operating procedures (SOPs) for beef cattle care and management. Short-term confinement of cows and calves in small paddocks (HDSD treatments) was conducted under approved protocol \#GRL-2016-10-19-1. Rumen fluid collected from rumen-cannulated beef steers and used to determine forage digestibility (IVTD) in the laboratory was conducted under approved protocol \#GRL-2018-6-12-1. All animal care and use SOPs and protocols were reviewed and approved by the Institutional Animal Care and Use Committee, Grazinglands Research Laboratory, El Reno, OK, USA.

\subsection{Statistical Analysis}

Means of $\rho_{\mathrm{b}}$, percent sand and clay, $\mathrm{pH}, \mathrm{EC}$, and biomass means were compared using Tukey's Honestly Significant Difference (HSD) test. All analyses were performed in JMP 13 Pro (SAS Institute, Cary, NC, USA), and the level of significance was set at $\alpha=0.05$. Descriptive statistics and linear least-squares regression of means ( $\alpha=0.5$ ) of plant biomass, herbage nutritive value, and soil properties were conducted in JMP Pro 14 (SAS Institute, Cary, NC, USA). Animal performance data were analyzed by ANOVA in SAS (SAS Institute, Cary, NC, USA) that included year as a random effect and grazing system (GS) and rep as fixed effects. Year $\times \mathrm{GS} \times$ rep was the error term. 


\section{Results}

\subsection{Temperature and Precipitation}

Box plots of temperature and precipitation during the 2009-2015 experimental years (Figure 3) show that the experimental years were highly variable but representative of the long-term climate in the region (Figure 1). Precipitation was especially variable during the months of May and July over the $6 \mathrm{yr}$ period. Average annual precipitation was below normal of $871 \mathrm{~mm}$ for the first four years of the study (557 to $795 \mathrm{~mm})$, above normal in $2013(1157 \mathrm{~mm})$, below normal in $2014(610 \mathrm{~mm})$, and above normal in 2015 (1273 mm).
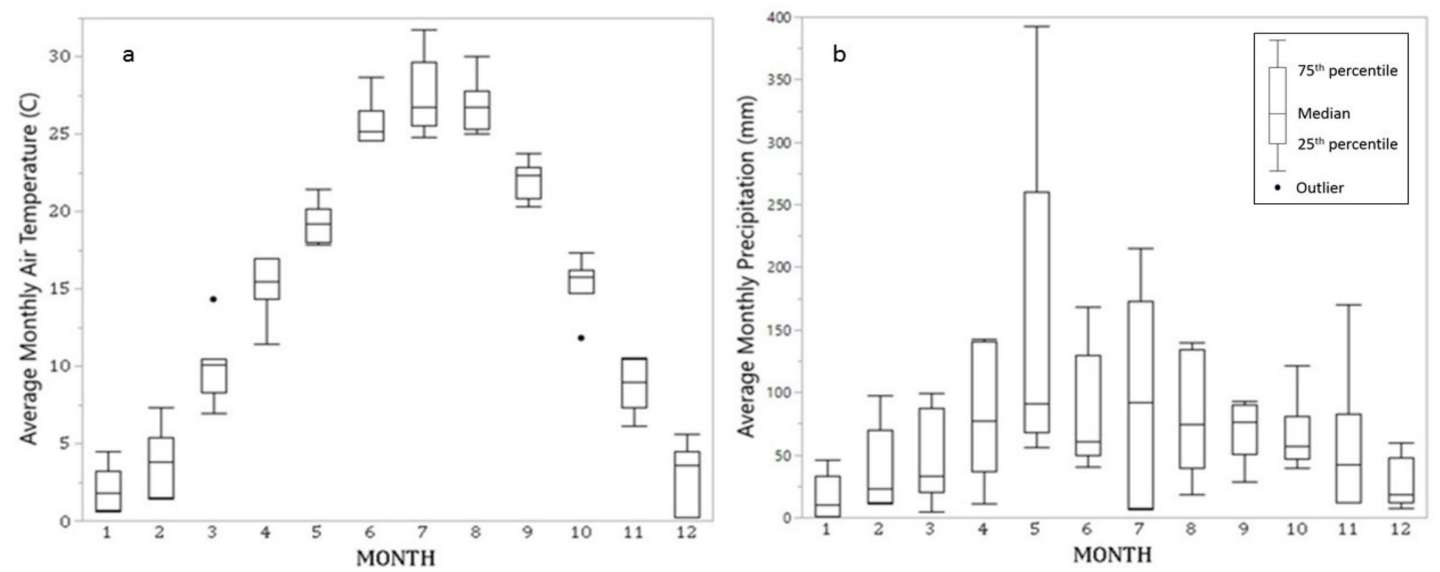

Figure 3. Box plots of monthly (a) temperature and (b) precipitation for 2009-2015, El Reno, Oklahoma. Month 1 = January ... Month 12 = December. Data Source: Oklahoma Climate Survey, http: //climate.ok.gov

\subsection{Soil parameters}

\section{Soil Bulk Density}

Averaged across measurements collected in 2009, 2012, and 2017, the $\rho_{b}$ of the $0-15 \mathrm{~cm}$ layer was $1.12 \mathrm{~g} \mathrm{~cm}^{-3}$ under CS management compared with $1.16 \mathrm{~g} \mathrm{~cm}^{-3}$ in RS management. While RS was higher density than CS $(p<0.05)$, the difference was minimal. There was no treatment effect on $\rho_{b}$ in the 15-30 cm layer across the three years. However, both treatment and year effects were significant, with $\rho_{\mathrm{b}}$ being higher in 2012 than in 2009 and 2017 (data not shown). Appendix A Table A2 shows that the initial samples from 2009 had slightly higher $\rho_{b}$ in the $0-15 \mathrm{~cm}$ layer in the RS replications than in the CS replicates, but that there was no difference between treatments in the surface layer in other years or at the 15-30 cm layer in any year. Samples from 2009 would not be expected to show treatment differences, since the treatments were initiated in 2008 , but represent variability at the site. Changes in soil characteristics after 2009 could be related to treatment; however no differences were found in 2012 or 2017.

\subsection{Forage}

\subsubsection{Above-Ground Biomass}

Biomass production was highly variable over the study and was highest in 2013 and lowest in 2011 and 2014 (Table 3). The year 2010 also showed a high level of biomass production, but was statistically lower $(p<0.05)$ than that of 2013 , while statistically greater than biomass production during the remaining years. Biomass production in 2010, 2009, 2012, 2014, and 2011 was 78\%, 58\%, $50 \%, 39 \%$, and $25 \%$, respectively, of amounts measured in 2013. No statistically significant differences between treatments were observed in end of season, which was expected as the samples were from 
ungrazed exclosures. There was also no difference by treatment in biomass collected through the growing seasons (data not shown).

Table 3. Avearge annual forage biomass production by year, pooled across treatments.

\begin{tabular}{cc}
\hline Year & $\begin{array}{c}\text { Biomass }^{\mathbf{1}} \\
\text { kg ha }^{-1}\end{array}$ \\
\hline 2009 & $4563^{\mathrm{C}}$ \\
2010 & $6084^{\mathrm{B}}$ \\
2011 & $2015^{\mathrm{D}}$ \\
2012 & $3992^{\mathrm{C}}$ \\
2013 & $7813^{\mathrm{A}}$ \\
2014 & $3127^{\mathrm{CD}}$ \\
\hline
\end{tabular}

${ }^{1}$ Site-specific means in the same column not connected by the same letter are statistically different $(\alpha=0.05)$ based on Tukey's Honestly Significant Difference (HSD).

\subsubsection{Monthly Mean and Variability of Forage Nutritive Values}

Monthly means of nutritive value during 2009 through 2014 illustrate the annual pattern of forage quality and level of variability (Figure 4). On average, N concentrations peaked in the May-June timeframe $(\approx 1.0 \%)$ and sharply decline thereafter, reaching minimum values by November $(\approx 0.6 \%)$. From November through March, total $\mathrm{N}$ remained low, but began to increase in April (Figure 4a). The ADF (Figure $4 b$ ) and NDF (Figure 4c) were highest in January through April and in November and December ( $\approx 50$ and $81 \%$, respectively). Lowest values of ADF and NDF occurred in June and July ( $\approx 41$ and $74 \%$, respectively). Typically, digestibility (IVTD, Figure $4 \mathrm{~d}$ ) was highest in June and July $(\approx 60 \%)$ and was generally above $50 \%$ in May through August. As indicated by the error bars in Figure 4 , interannual variability was considerable for all forage nutritive variables shown, especially in the months April through July.
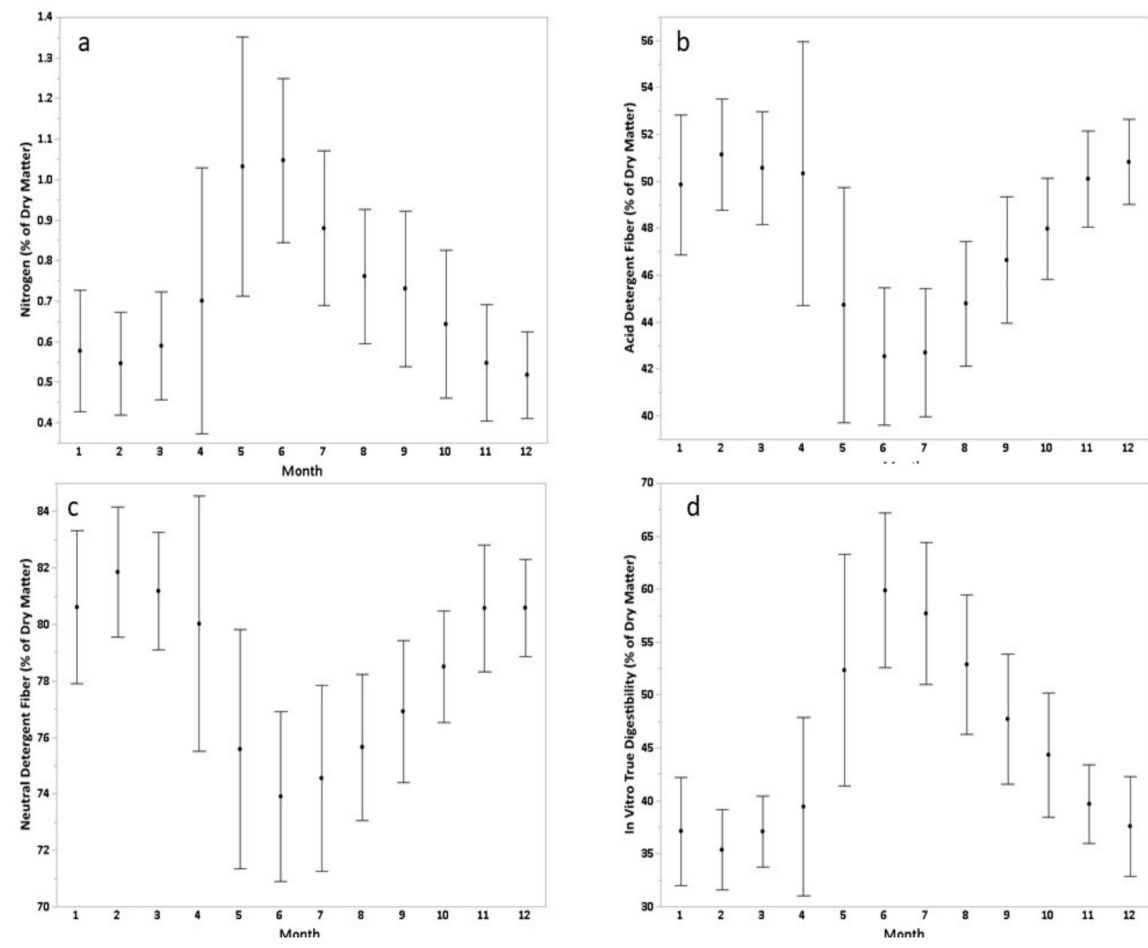

Figure 4. Monthly mean concentrations of (a) total nitrogen, (b) acid detergent fiber, (c) neutral detergent fiber, and (d) in vitro true dry matter digestibility of standing biomass. Error bars are \pm 1 standard deviation. Month 1 = January ... Month 12 = December. 


\subsubsection{Forage Nutritive Values during Summer Grazing Season}

Mean concentrations of total N (Table 4) were highest in 2009, but statistically similar to that of 2010, and lowest in 2011. Mean ADF concentration was highest in 2011 but statistically similar to that observed in 2009 and 2014. ADF was lowest in 2010, which was similar to that measured in 2013. Mean NDF was highest in 2011 (significantly different than all other years) and lowest in 2013. Mean IVTD was highest in 2010 and lowest in 2011. Statistical differences were observed for some forage nutritive values at the treatment level. While small, when they differed, total $\mathrm{N}$ concentration was higher in RS than in CS in 2011, 2013, and 2015; IVTD was higher in RS than in CS in 2012-2015; and ADF and NDF were lower in RS than in CS in 2013 and 2015.

Table 4. Comparison of treatment $(\mathrm{CS}=$ continuous stocking, $\mathrm{RS}=$ rotational stocking) means of concentrations (\% of dry matter) of total nitrogen $(\mathrm{N})$, acid detergent fiber (ADF), neutral detergent fiber (NDF), and in vitro true digestibility (IVTD) by year of study.

\begin{tabular}{|c|c|c|c|c|c|c|c|c|}
\hline \multirow[b]{2}{*}{ Year } & \multicolumn{2}{|c|}{$\mathbf{N}$} & \multicolumn{2}{|c|}{ ADF } & \multicolumn{2}{|c|}{ NDF } & \multicolumn{2}{|c|}{ IVTD } \\
\hline & CS & RS & CS & RS & CS & RS & CS & RS \\
\hline 2009 & 1.0 & 1.0 & 46.0 & 45.3 & 76.3 & 76.1 & 54.5 & 56.8 \\
\hline 2010 & 0.95 & 0.93 & 42.5 & 42.9 & 75.3 & 76.4 & 59.2 & 59.0 \\
\hline 2011 & $0.60^{b}$ & $0.65^{a}$ & 48.1 & 47.3 & 79.6 & 78.9 & 41.2 & 41.7 \\
\hline 2012 & 0.72 & 0.75 & 47.0 & 46.4 & 77.1 & 76.9 & $42.1^{b}$ & $45.4^{a}$ \\
\hline 2013 & $0.74^{b}$ & $0.87^{a}$ & $47.0^{a}$ & $45.0^{b}$ & $77.2^{a}$ & $75.6^{b}$ & $45.6^{b}$ & $52.1^{a}$ \\
\hline 2014 & 0.63 & 0.65 & 48.8 & 49.7 & 79.9 & 79.6 & $42.2^{b}$ & $46.0^{\mathrm{a}}$ \\
\hline 2015 & $0.72^{b}$ & $0.82^{a}$ & $49.2^{a}$ & $46.5^{b}$ & $78.5^{a}$ & $76.3^{b}$ & $39.4^{b}$ & $47.2^{\mathrm{a}}$ \\
\hline Mean & $0.74^{b}$ & $0.80^{a}$ & $47.0^{a}$ & $46.3^{b}$ & $77.8^{a}$ & $77.0^{b}$ & $45.8^{b}$ & $49.5^{a}$ \\
\hline
\end{tabular}

\subsection{Animal Parameters}

\subsubsection{Stocking Rate}

Stocking rate by replicate and year are shown in Figure 5. Analyzed across the experimental period, the CS and RS stocking rates did not differ $(p=0.05)$. As discussed below, stocking rates in CS replicates were reduced in the latter years of the study.

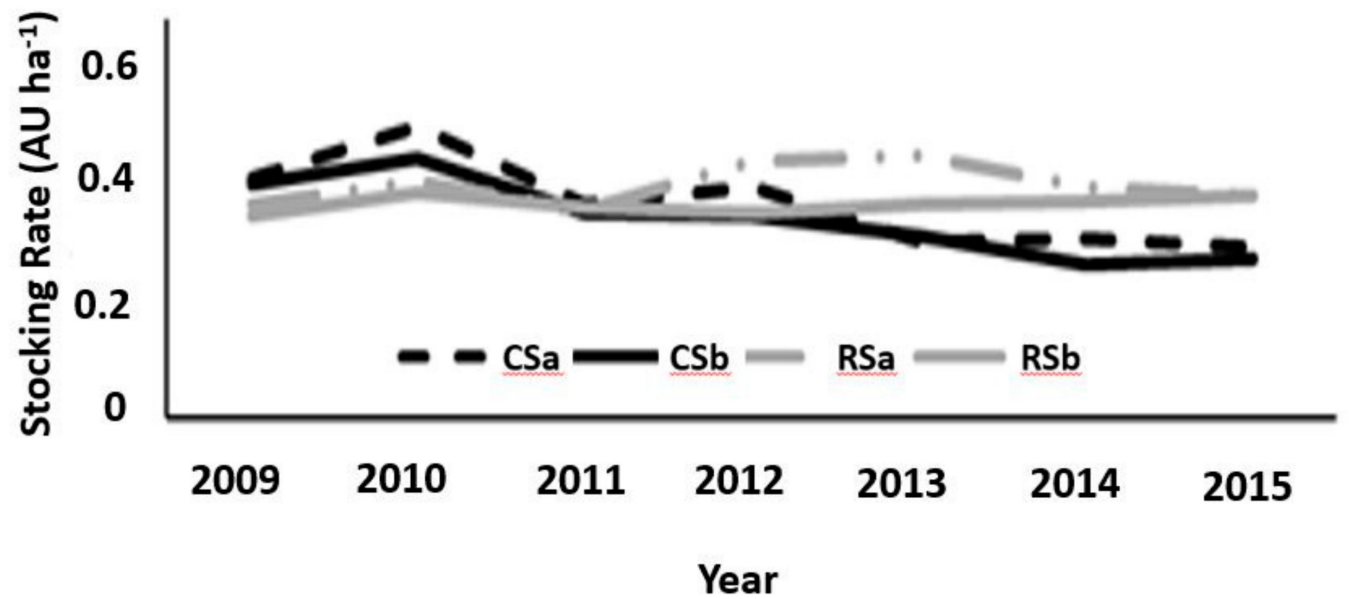

Figure 5. Stocking rate for each replicate from 2009 to 2015. 


\subsubsection{Animal Performance}

Cow-calf performance measures are presented by management and year, since no management $X$ year interactions were observed (Table 5). Years 2010 and 2011 were not utilized for statistical analysis. In 2010, data collection was compromised by faulty livestock scales. In spring 2011, a tornado caused catastrophic damage to our animal research facilities, including pasture areas, which hindered the research and collection of data. All animal measurements were taken in the fall, at the time of calf weaning. Fall cow BCS and calf weaning weight (WW) were higher in the CS treatment compared with RS, which could be indicators of either herbage nutritive value or intake (Coleman et al. [57]). Cow BCS varied between years, with 2014 being greater than $2015(p<0.05)$, and both of those years being greater than previous years. Calf WW also impacted by year $(p<0.01)$, with 2013 being the highest and 2015 being the lowest. When slight differences in stocking rate and calf weaning percentage were considered, no differences were observed in WW per cow AU or total calf $\mathrm{kg} \mathrm{WW} \mathrm{ha}^{-1}$ due to grazing system.

Table 5. Effect of grazing system (GS) and year on cow body weight (BW), body condition score (BCS), calf weaning weight (WW), WW per cow AU, and WW per ha.

\begin{tabular}{|c|c|c|c|c|c|c|c|c|c|c|c|}
\hline \multirow[t]{2}{*}{ Measurement } & \multicolumn{4}{|c|}{ Continuous Stocking } & \multicolumn{5}{|c|}{ Rotational Stocking } & \multirow{2}{*}{\multicolumn{2}{|c|}{$p$ value }} \\
\hline & \multicolumn{2}{|c|}{ Mean } & \multicolumn{2}{|c|}{ SE } & \multicolumn{3}{|c|}{ Mean } & \multicolumn{2}{|c|}{ SE } & & \\
\hline Cow BW, kg & \multicolumn{2}{|c|}{640} & \multicolumn{2}{|c|}{6.0} & \multicolumn{3}{|c|}{630} & \multicolumn{2}{|c|}{4.9} & \multicolumn{2}{|c|}{0.2122} \\
\hline Cow BCS & \multicolumn{2}{|c|}{$5.8^{a}$} & \multicolumn{2}{|c|}{0.06} & \multicolumn{3}{|c|}{$5.6^{b}$} & \multicolumn{2}{|c|}{0.05} & \multicolumn{2}{|c|}{0.0021} \\
\hline Calf WW, kg & \multicolumn{2}{|c|}{$235^{a}$} & \multicolumn{2}{|c|}{7.6} & \multicolumn{3}{|c|}{$215^{b}$} & \multicolumn{2}{|c|}{6.2} & \multicolumn{2}{|c|}{0.0477} \\
\hline WW ha ${ }^{-1}, \mathrm{~kg}$ & \multicolumn{2}{|c|}{59} & \multicolumn{2}{|c|}{2.1} & \multicolumn{3}{|c|}{61} & \multicolumn{2}{|c|}{1.7} & \multicolumn{2}{|c|}{0.6342} \\
\hline \multirow{2}{*}{ Measurement ${ }^{1}$} & \multicolumn{9}{|c|}{ Year } & & $p$ value \\
\hline & 2009 & SE & 2012 & SE & 2013 & SE & 2014 & SE & 2015 & SE & \\
\hline Cow BW, kg & 638 & 7.8 & 640 & 8.7 & 637 & 9.2 & 623 & 8.8 & 637 & 9.0 & 0.6538 \\
\hline Cow BCS & $5.5^{c}$ & 0.07 & $5.5^{\mathrm{c}}$ & 0.08 & $5.6^{b c}$ & 0.09 & $6.1^{a}$ & 0.08 & $5.8^{b}$ & 0.09 & $<0.0001$ \\
\hline Calf WW, kg & 232 & 9.9 & 219 & 11.0 & 243 & 11.7 & 225 & 11.1 & 208 & 11.4 & 0.2730 \\
\hline WW Cow-AU ${ }^{-1}, \mathrm{~kg}$ & 183 & 8.1 & 170 & 9.0 & 195 & 9.6 & 181 & 9.1 & 168 & 9.4 & 0.2689 \\
\hline WW ha ${ }^{-1}, \mathrm{~kg}$ & $74^{\mathrm{a}}$ & 2.7 & $59^{b}$ & 3.0 & $57^{b}$ & 3.1 & $58^{\mathrm{b}}$ & 3.0 & $53^{b}$ & 3.1 & $<0.0001$ \\
\hline
\end{tabular}

\section{Discussion}

The 2011-2012 drought resulted in poor plant productivity and vigor, particularly on the " $\mathrm{A}$ " replicates; increased brushy vegetation was observed in the CSa replicate (reference [58], this issue). Based on the observation of forage availability following drought periods in 2011 and 2012, stocking rate was reduced slightly on the CS grazing treatments in 2013. However, the 2009-2015 mean stocking rate did not differ for CS and RS grazing system (Figure 5).

Plant biomass did not differ between CS and RS grazing systems, but there were significant year effects, which were mainly related to the timing and amount of rainfall received. Forage quality naturally changes throughout the season, but it also was impacted by the timing and amount of rainfall. Statistically significant treatment effects were observed for some forage nutritive values, and while these differences were small, when they occurred, they indicated higher nutritive value in RS than in CS treatment The plant nutritional values (Table 4) were determined from clipped biomass (whole plant samples). Nutritive value of forage evaluated from clipped samples is influenced by many factors including climate and ambient temperature, water stress, soil nutrient (fertility) levels, plant species, cultivar, stage of maturity, leaf-to-stem ratio, plant pests and disease, and management [59]. When related to herbage production and nutritive value estimates, there is no clear relationship with animal productivity. This lack of relationship is indicative that other "system" factors (including animal behavior) are impacting animal responses. Animal performance is related to the forage actually selected and consumed by the grazing animal. In this study, cow BCS and calf BW, both taken at weaning, were greater for CS than for RS, indicating greater DM intake [57] and perhaps greater diet 
selection. Cows on CS had more area from which to select. The nature of management of RS is to force/encourage animals to more uniformly graze the available herbage, and may result in lower diet nutritive value or lower intake.

A collection of papers present additional findings from this experiment to date. Reference [44] reported that the Standardized Precipitation and Evaporation Index (SPEI) has potential for use as a predictive tool for aboveground biomass and thus could provide an early indicator of above- or below-average forage production, which could benefit land and herd management. Findings in this paper that aboveground biomass was not different in CS and RS grazing systems, based on clipping, is similar to results of reference [60], who applied remote sensing techniques to calculate gross primary productivity and the enhanced vegetative index (EVI), which also reported no significant treatment effect for grazing systems. They also reported that variations in EVI among paddocks managed with rotational stocking were small relative to paddocks managed with continuous stocking, suggesting that rotational stocking generated a more uniform grazing pressure on vegetation at annual scale. Overall, climate and inherent pasture conditions are the major drivers of plant growth and productivity.

While individual calf WW was higher in CS grazing systems than in RS grazing systems (Table 5), productivity expressed as calf WW ha ${ }^{-1}$ was not different in the two grazing systems, which is consistent with the findings of [61] that different grazing systems did not affect gain of stocker cattle in South Africa. Economics of forage-based livestock systems are driven by several factors, but productivity and income per unit land area are key for decision-making. Calf rate of gain and WW are determined by genetic influence of both sire and dam, normally defined by mature size, but also by milk production. Both milk production and calf WW were highly related to herbage DM intake by their dams [57], suggesting those management decisions that affect availability and quality of herbage on offer will affect productivity. If RS management can increase forage nutritive value, then animal performance may be improved. However, in this study, the individual calf WW was higher in CS than in RS systems, but total weaned calf weight per unit area did not differ across treatments. Therefore, producers should perhaps look for changes in other response variables such as soil conditions, plant community dynamics, or total forage production as indicators of system effects.

Reference [55] reported that total, particulate, microbial biomass and mineralizable carbon and $\mathrm{N}$ fractions were highly stratified with depth and that no significant differences in soil organic carbon and $\mathrm{N}$ fractions occurred due to stocking method at any sampling time or depth. Evidence for biological nitrification inhibition in both treatments suggested a mechanism for conservation of available soil $\mathrm{N}$ with less opportunity for loss in the prairie soils. In addition, strong association of available $\mathrm{N}$ with biologically active carbon indicated slow, but sustained release of $\mathrm{N}$ that was strongly coupled to carbon cycling.

Reference [42] reported that effects of stocking methods on macronutrient availability in soil and spatial distribution of macronutrients in soil [43] were variable and often difficult to define. All tested grazing regimes affected soil levels of availability and flux of macronutrients at different times of growing season, and among locations in paddocks. Such responses indicated grazing regimes may not provide uniform distribution of labile macronutrients. The grazing regimes tested appeared to generate localized increases in plant-available macronutrients with change in time of growing season, and among paddock locations, indicating no one system of grazing will prevent hot spots of soil macronutrient availability and flux. This result indicated that organization of the landscape included within the boundaries of individual paddocks played a role in distribution, but actual distances from sampled locations to water sources had less of a material effect on nutrient distributions.

Reference [60] analyzed the phenology and gross primary production of tallgrass pastures in response to CS and RS management systems in drought and non-drought years and found that both the CS and RS grazing systems were resilient to drought, probably due to the conservative stocking rates applied during the study. Spatial patterns of landscape metrics (richness, evenness, and fragmentation) were evaluated for CS and RS grazing system by reference [58], who indicated that shrub encroachment was mainly controlled by the initial status of the pastures rather than the grazing system. Their study 
also indicated higher proportion of bare soil occurred in RS sub-paddocks that were being grazed or were recently grazed, compared with the CS treatments.

\section{Conclusions}

In developing the initial study, input from ranchers, conservationists, and others was solicited to identify the most important knowledge gaps, relevant evaluation criteria, and grazing systems of interest. The research was designed in a way to facilitate transfer of knowledge to ranchers. However, due to turnover of key staff, the connection to the producer group was not maintained to the extent envisioned.

Findings to date indicate that plant biomass and animal productivity of the two grazing management systems were similar. There were some indicators that forage nutritive value and soil nutrient content were enhanced in the RS system compared with the CS system, though differences were small and not supported by animal productivity. Analyses of these results prepares us to engage with producers to share the findings. With minimal differences in plant and animal productivity, future research should continue to evaluate changes in soil and plant ecological responses. Additionally, researchers should explore with producers alternative production practices that might increase productivity or profitability and enhance ecological responses. Methods to improve the overall responses to the applied grazing systems might include the use of applied spring burns to manipulate the herbaceous community and eliminate areas of standing dead biomass and provide uniform stands of higher quality biomass, use of patch burning [62] to enhance biodiversity of paddocks, or use of strip grazing to provide more uniform use of paddock and sub-paddock areas. Detailed assessment of vegetative and soil biodiversity may identify responses that plant biomass monitoring and soil nutrient analysis did not detect to date.

Author Contributions: Author contributions are as follows: J.L.S: conceptualization, methodology, original draft preparation, administration, funding acquisition; P.J.S: conceptualization, methodology, formal analysis, writing original draft, and writing and editing; J.P.S.N.: formal analysis, investigation, writing —original draft preparation; B.N. conceptualization, methodology, data curation, writing-review and editing; K.E.T.: forage nutritive value assessment, and writing — review and editing; P.G. supervision, resources, writing - review and editing, project administration; S.C.: methodology, project administration, writing- review and editing; M.B. investigation, supervision, writing-review and editing.

Funding: This research is a contribution from the Long Term Agroecosystem Research (LTAR) network, a project of the USDA-ARS, and was partially supported by funds from the Agriculture and Food Research Initiative Competitive Projects 2012-02355 and 2013-69002-23146 from the USDA National Institute of Food and Agriculture.

Acknowledgments: This project was established to address concerns of ranchers raised at a workshop in 2008 attended by USDA-ARS, USDA-NRCS, the Oklahoma Grazing Lands Conservation Association, the Holistic Management Institute, and Texas AgriLife. The authors gratefully acknowledge the leadership of Dr. Brad Venuto (posthumously) in the establishment of this project. Site management and data collection efforts of Clendon Tucker, Dr. David Von Tungeln, Scott Schmidt, Pat King, Bill Jensen, and many others were critical to this project. Additional researchers have been engaged over time, as evidenced by authorship on this collection of papers.

Conflicts of Interest: The authors declare no conflict of interest.

Disclaimer: Mention of trade names or commercial products is this publication is solely for the purpose of providing specific information and does not imply recommendation or endorsement by the U.S. Department of Agriculture. USDA is an equal opportunity provider and employer.

\section{Appendix A}

\section{Appendix A.1 High-Density, Short-Duration (HDSD) Treatments}

In addition to the grazing system experiment, an additional study utilized two sets of two small paddocks (0.405 and 0.202 ha) that were established as exclosures within each of the continuous paddocks (see Figure 2) to examine impacts of high-density short-duration (HDSD) stocking on vegetation and soil characteristics. Each year, the herd assigned to each CS paddock were confined within the 0.405 ha paddocks (HDSDx1) for $24 \mathrm{~h}$, returned to the CS paddock overnight, then confined 
into a 0.202 ha paddocks (HDSDx2) for $24 \mathrm{~h}$ (Appendix A). No HDSD occurred in 2012 due to severe drought conditions. The removal of animals for no more than 2 days per year for the embedded stock density experiment was assumed to have a negligible impact on the CS treatment. To avoid unintended plant community shifts caused by high-density grazing in any particular season, the timings of these treatments were sequenced to be different months in different years.

\section{Appendix A.2 Soil Water Content by Depth}

The only soil water measurements available for this study were from the USDA-NRCS Soil and Climate Analysis Network (SCAN; https://www.wcc.nrcs.usda.gov/ scan/) site that was installed in the study area in late 1998 . Hourly soil volumetric water content $(\theta \mathrm{v})$, at the 5, 10, 20, 50, and $100 \mathrm{~cm}$ (nominally) depths, are measured with a Hydroprobe (Steven's Water Inc., Grants Pass, OR, USA). Due to electronic issues, measurements at the 5 and $10 \mathrm{~cm}$ depths were not recorded from November 2014 through June 2015. Measurements from the 20 and $50 \mathrm{~cm}$ depths were not recorded from September 2011 through July 2013, and data from the $100 \mathrm{~cm}$ depth are missing from November 2014 through June 2015. However, enough data was available to calculate a simple soil profile average for most of the study period.

The averaged measured monthly soil $\theta_{\mathrm{v}}$ for the $-100 \mathrm{~cm}$ profile and $5,10,20,50$, and $100 \mathrm{~cm}$ depths are shown in Figures A1-A6. At the $5 \mathrm{~cm}$ depth (Figure A2), with only two exceptions, $\theta \mathrm{v}$ was typically $>15 \%$ during the 2008-2010 timeframe. However, due to low precipitation amounts beginning in December of 2010, a steady drying of the soil occurred at this depth. For most of the period from April to November 2011, $\theta \mathrm{v}$ was $>15 \%$. The relatively large rainfall events in late 2011 and early 2012 served to bring $\theta \mathrm{v}>15 \%$, which lasted through May of 2012. Beginning in June of 2012, however, $\theta \mathrm{v}$ was again $<15 \%$, briefly rebounding to $20 \%$ in October, and then falling below $15 \%$ in November and December 2012. Precipitation in 2013 was above normal, and this is reflected in the $5 \mathrm{~cm} \theta \mathrm{v}$ measurements, where $\theta \mathrm{v}$ was $>19 \%$ in all months and $>25 \%$ in seven months. Although 2014 was a below-normal rainfall year, the rainfall amounts received enabled $\theta \mathrm{v}$ to stay above $16 \%$ in all months for which data were available. The data for the November 2014 through June 2015 was not available, but the precipitation data suggest that $\theta \mathrm{v}$ was likely $>15 \%$ during this time period. Only four of the 30 months from July 2015 through December 2017 exhibited $\theta \mathrm{v}<15 \%$.

Time periods where $\theta \mathrm{v}$ at the $10 \mathrm{~cm}$ depth (Figure A3) falls below 15\% are largely similar to those observed at the $5 \mathrm{~cm}$ depth. Some exceptions include: in $2011, \theta \mathrm{v}$ at $10 \mathrm{~cm}$ is $<15 \%$ only in three months, whereas at $5 \mathrm{~cm}$, six months were $<15 \%$; in 2012, $\theta \mathrm{v}$ was $<15 \%$ in four months vs. 6 months at $5 \mathrm{~cm}$; no month was below 15\% in 2015, 2016, or 2017.

Two 7 to 8 month long time periods were observed where $\theta \mathrm{v}<13 \%$ was observed at the $50 \mathrm{~cm}$ depth (Figure A5): July 2009 through January 2010 and August 2012 through March 2013. One- to two-month-long periods occurred in November of 2011, January of 2015, and December of 2016. Profile averages of $\theta \mathrm{v}$ (Figure A1) indicated July of 2008 and 2009, June of 2010, July through September 2011, January of 2012, and July through September and December of 2012 were $\leq 13 \%$. The $50 \mathrm{~cm}$ (Figure A5) and $100 \mathrm{~cm}$ (Figure A6) depths showed similar patterns. 


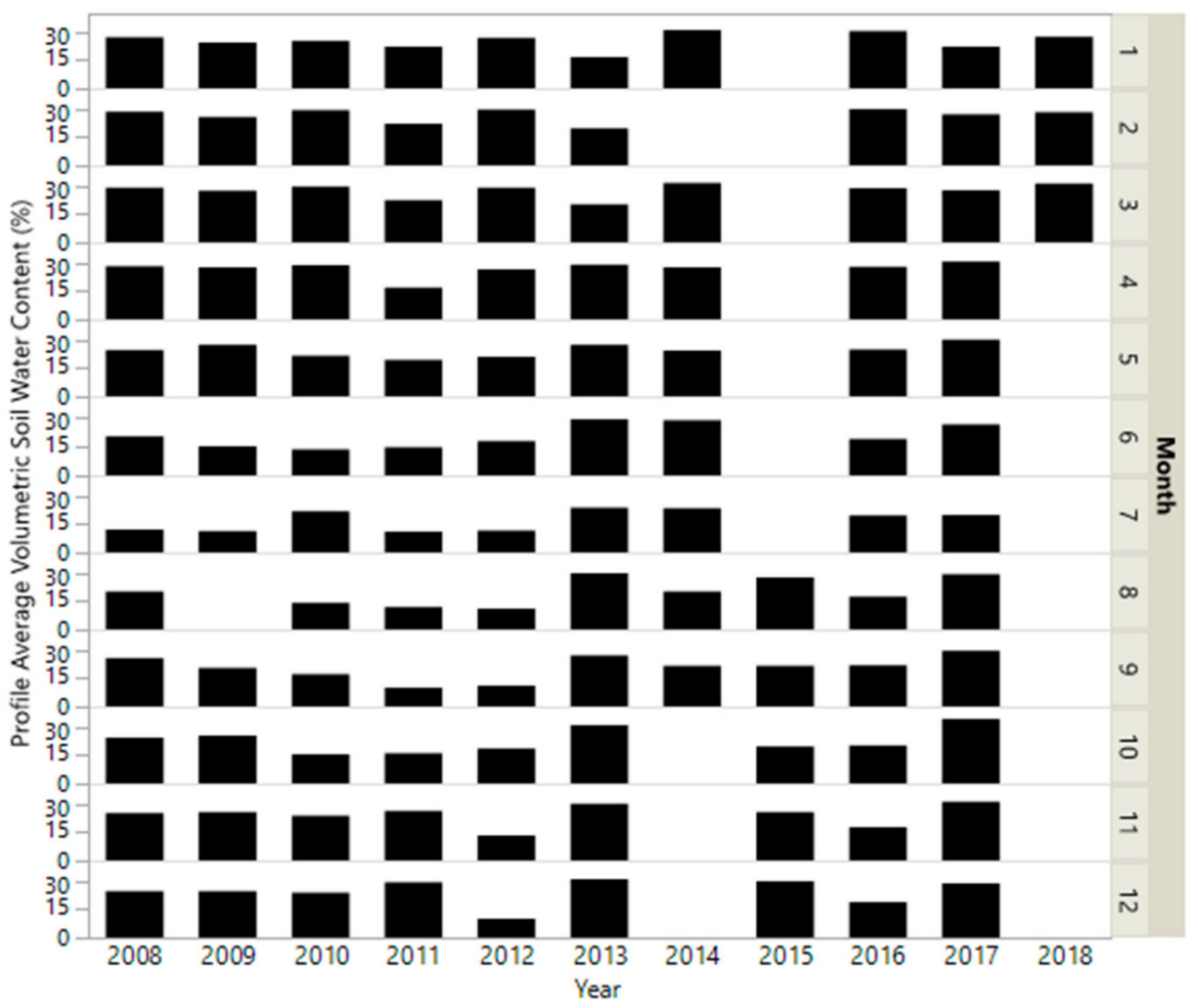

Figure A1. Monthly average volumetric water content (\%) for the $0-100 \mathrm{~cm}$ profile by year.

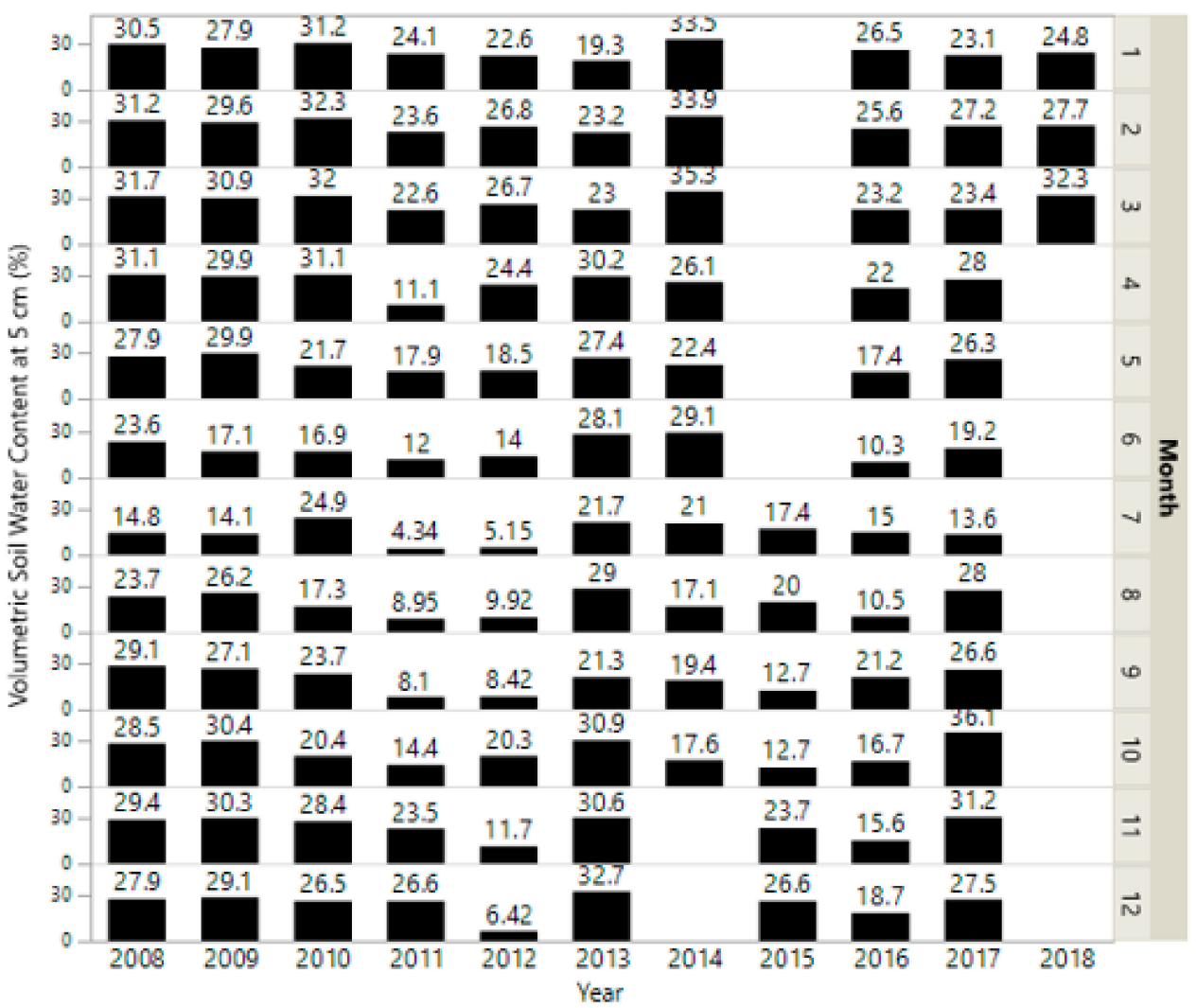

Figure A2. Monthly average volumetric water content (\%) at $5 \mathrm{~cm}$ depth by year. 


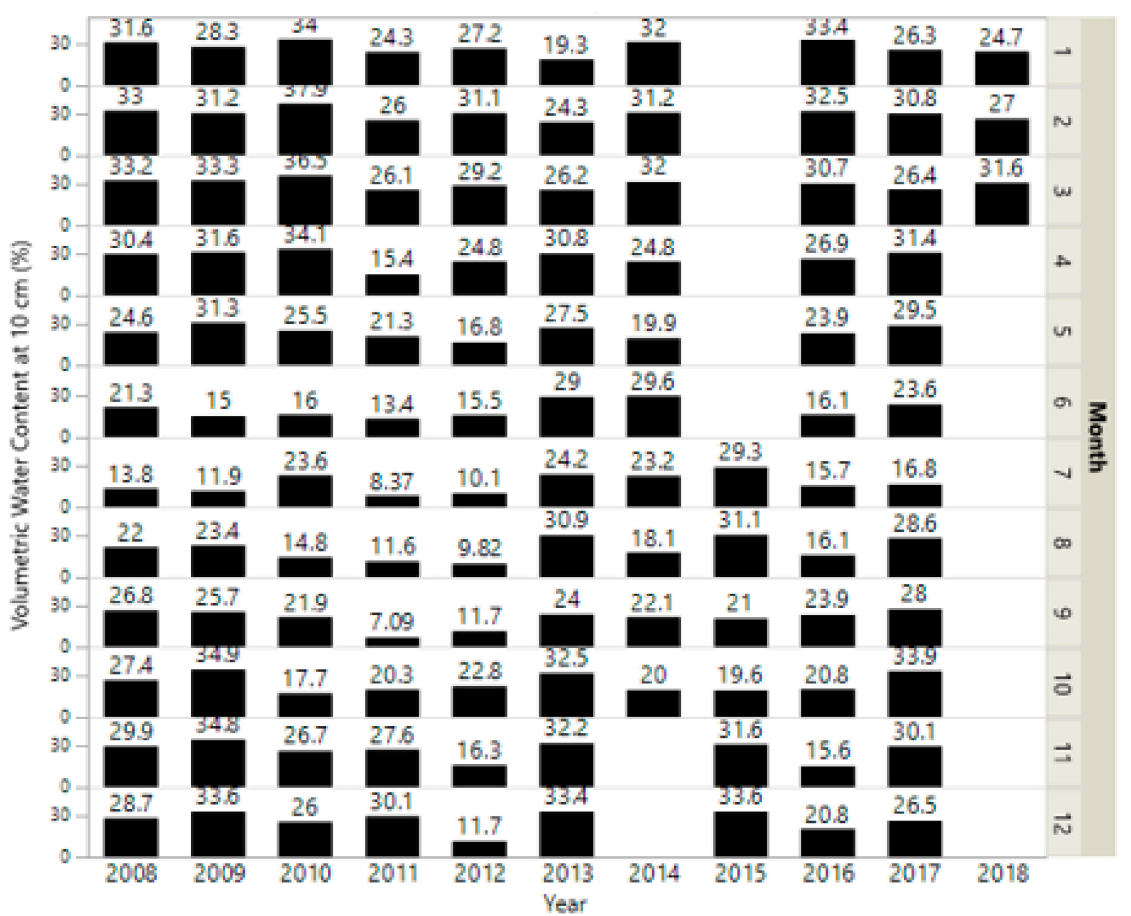

Figure A3. Monthly average volumetric water content (\%) at $10 \mathrm{~cm}$ depth by year.

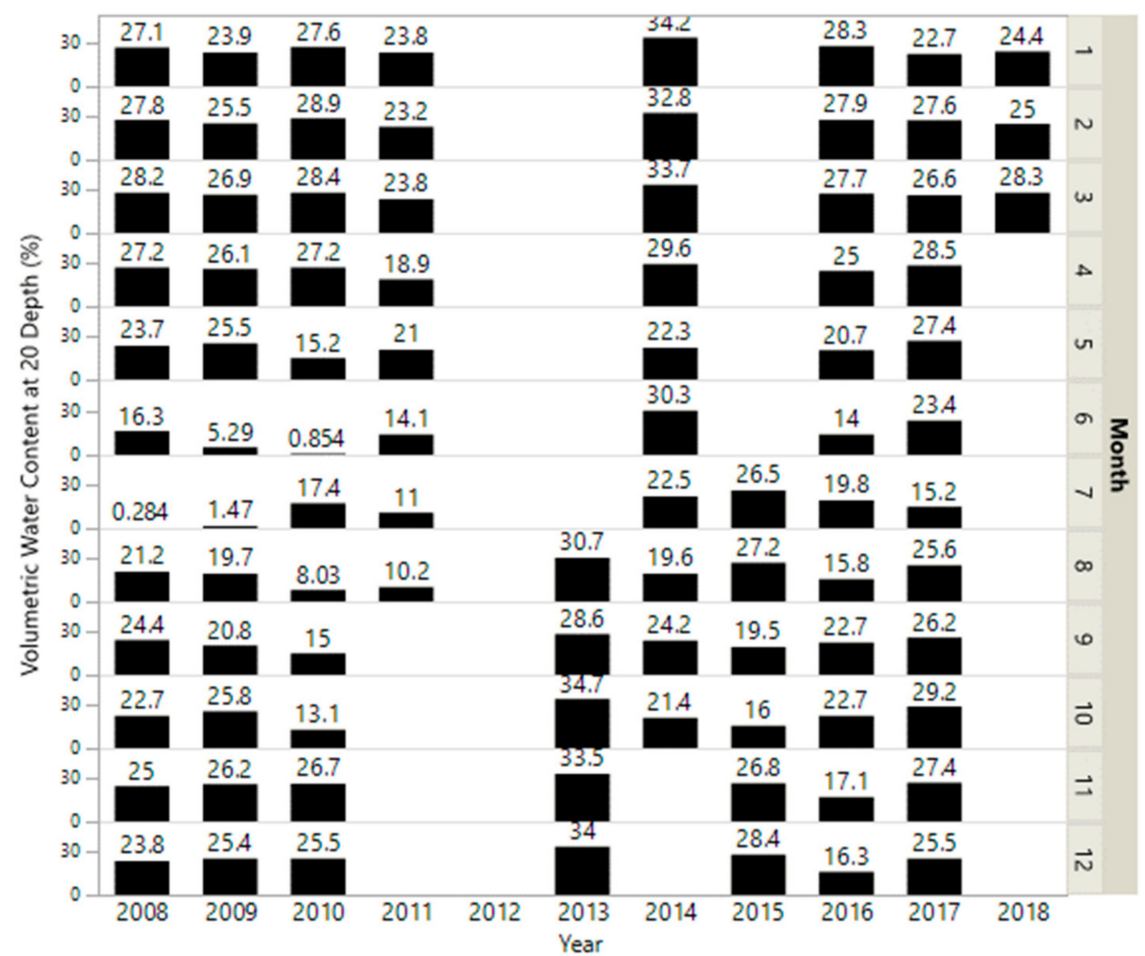

Figure A4. Monthly average volumetric water content (\%) at $20 \mathrm{~cm}$ depth by year. 


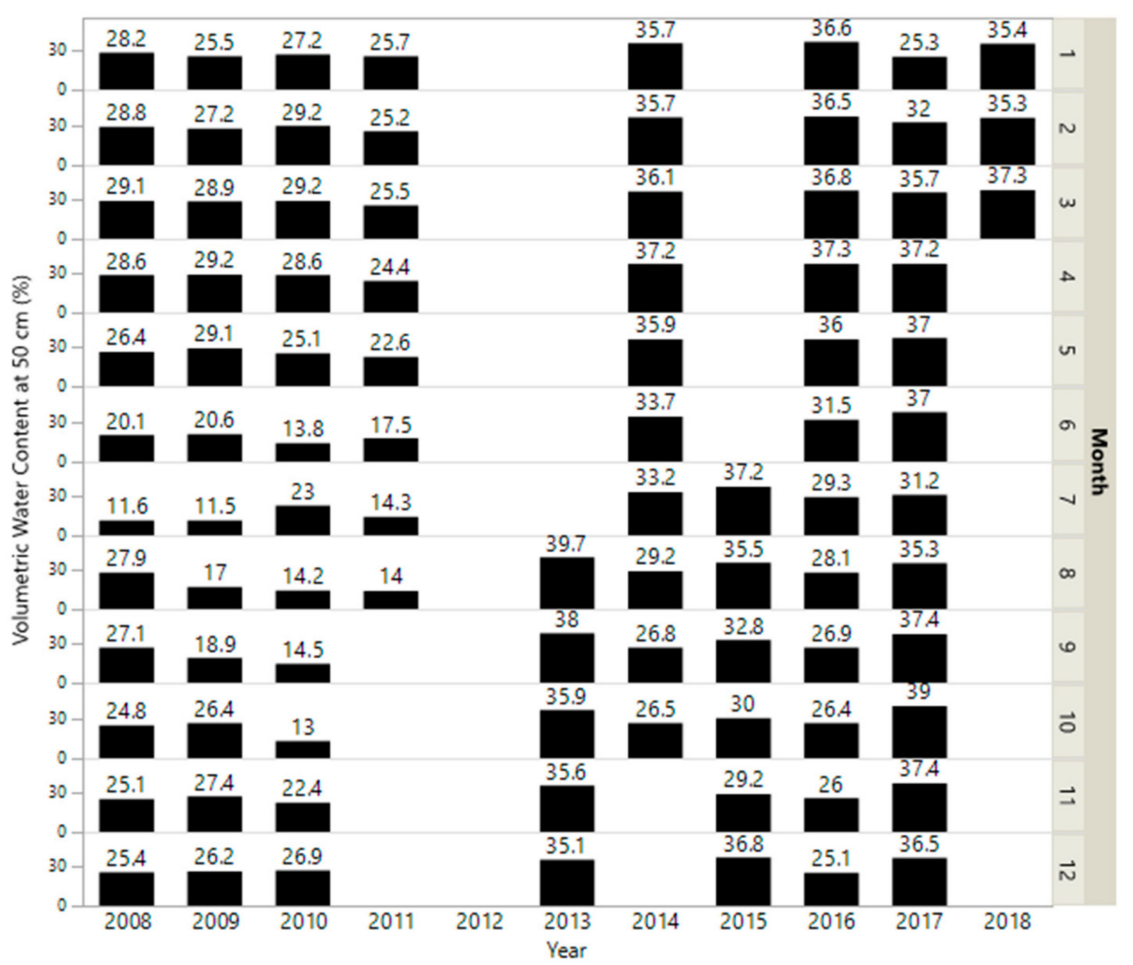

Figure A5. Monthly average volumetric water content (\%) at $50 \mathrm{~cm}$ depth by year.

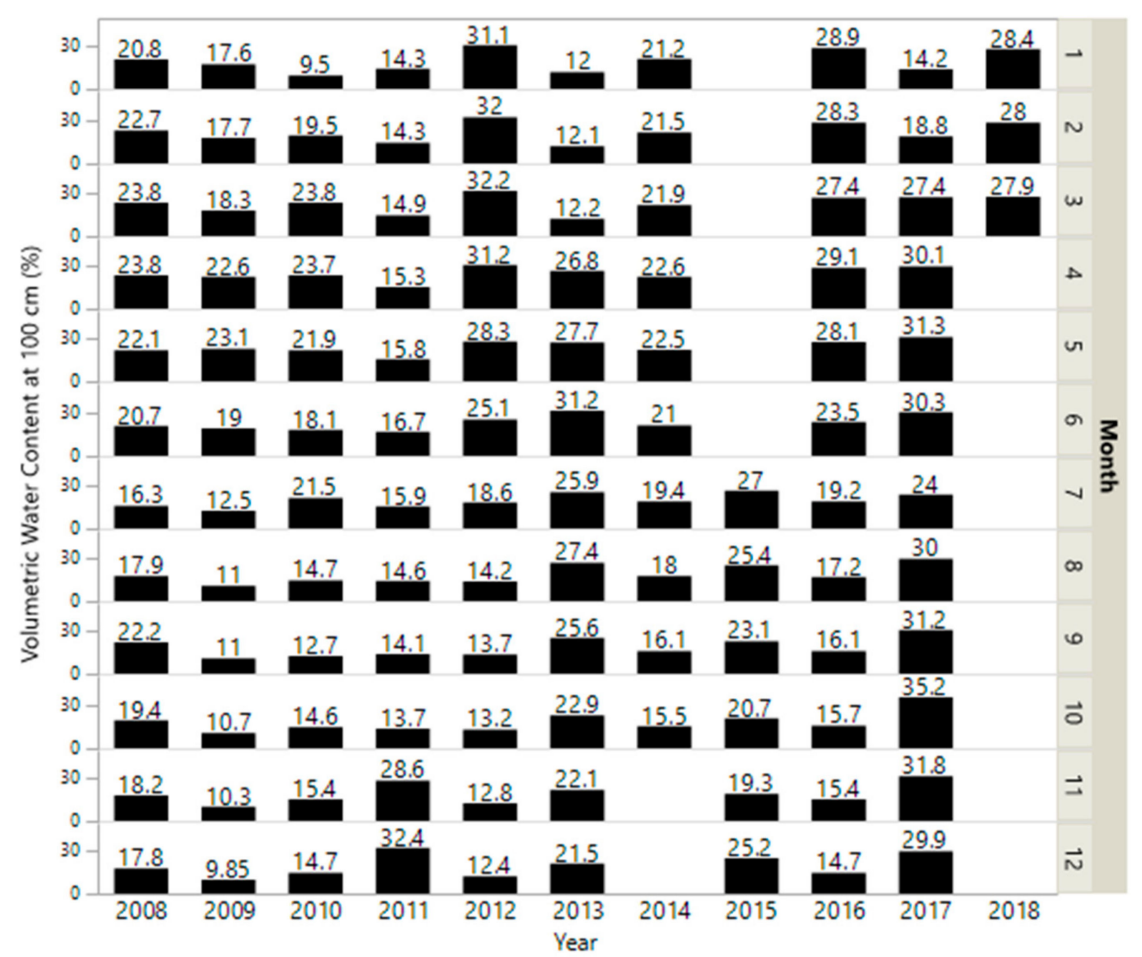

Figure A6. Monthly average volumetric water content (\%) at $100 \mathrm{~cm}$ depth. 
Appendix A.3 Soil Properties

Table A1. Means of percent sand and clay and $\mathrm{pH}$ and electrical conductivity (EC) by layer for each treatment.

\begin{tabular}{|c|c|c|c|c|c|c|}
\hline \multirow[t]{2}{*}{ Treatment ${ }^{\dagger}$} & $\%$ Sand & \% Clay & \multicolumn{2}{|c|}{$\mathrm{pH}$} & \multicolumn{2}{|c|}{$\mathrm{EC}\left(\mathrm{uS} \mathrm{cm} \mathrm{cm}^{-1}\right)$} \\
\hline & \multicolumn{2}{|c|}{$0-30 \mathrm{~cm}$} & $0-15 \mathrm{~cm}$ & $15-30 \mathrm{~cm}$ & $0-15 \mathrm{~cm}$ & $15-30 \mathrm{~cm}$ \\
\hline $\mathrm{CS}$ & $26.7^{\mathrm{A}}$ & $23.1^{\mathrm{A}}$ & $6.1^{\mathrm{A}}$ & $5.92^{\mathrm{A}}$ & $329.8^{\mathrm{A}}$ & $260.0^{\mathrm{A}}$ \\
\hline RS & $22.6^{\mathrm{A}}$ & $25.3^{\mathrm{A}}$ & $6.1^{\mathrm{A}}$ & $6.02^{\mathrm{A}}$ & $292.8^{\mathrm{A}}$ & $207.5^{\mathrm{A}}$ \\
\hline
\end{tabular}

Table A2. Average bulk density for the two soil layers as a function of year $\times$ treatment effects.

\begin{tabular}{|c|c|c|}
\hline \multirow{2}{*}{ Year, Treatment ${ }^{\dagger}$} & \multicolumn{2}{|c|}{ Depth Interval } \\
\hline & $0-15 \mathrm{~cm}$ & $15-30 \mathrm{~cm}$ \\
\hline & \multicolumn{2}{|c|}{$\mathrm{g} \mathrm{cm}^{-3}$} \\
\hline $2009, \mathrm{CS}$ & $1.04 \mathrm{C}^{\mathrm{O}}$ & $1.21^{\mathrm{B}}$ \\
\hline $2009, \mathrm{RS}$ & $1.12^{\mathrm{B}}$ & $1.21^{\mathrm{B}}$ \\
\hline $2012, \mathrm{CS}$ & $1.28^{\mathrm{A}}$ & $1.35^{\mathrm{A}}$ \\
\hline $2012, \mathrm{RS}$ & $1.28^{\mathrm{A}}$ & $1.33^{\mathrm{A}}$ \\
\hline 2017, CS & $1.05^{\mathrm{C}}$ & $1.14^{\mathrm{C}}$ \\
\hline 2017, RS & $1.07^{\mathrm{BC}}$ & $1.16^{\mathrm{C}}$ \\
\hline
\end{tabular}

\section{References}

1. Bigelow, D.P.; Borchers, A. Major Uses of Land in the United States, 2012; EIB-178; United States Department of Agriculture: Economic Research Service: Washington, DC, USA, 2018.

2. Steiner, J.L.; Franzluebbers, A.J.; Neely, C.; Ellis, T.; Aynekulu, E. Enhancing soil and landscape quality in smallholder grazing systems. In Soil Management of Smallholder Agriculture. Advances in Soil Science; Lal, R., Ed.; CRC Press: Boca Raton, FL, USA, 2014; pp. 63-111.

3. Panunzi, E. Are Grasslands under Threat? Brief Analysis of FAO Statistical Data on Pasture and Fodder Crops; UN Food and Agriculture Organization: Rome, Italy, 2008.

4. Neely, C.; Bunning, S.; Wilkes, A. Review of Evidence on Drylands Pastoral Systems and Climate Change; Land and Water Discussion Paper No. 8; Food and Agriculture Organization of the United Nations: Rome, Italy, 2009.

5. Smith, M.R.; Myers, S.S. Impact of anthropogenic $\mathrm{CO}_{2}$ emissions on global human nutrition. Nat. Clim. Chang. 2018, 8, 834-839. [CrossRef]

6. Brussaard, L.; Caron, P.; Campbell, B.; Lipper, L.; Mainka, S.; Rabbinge, R.; Babin, D.; Pulleman, M. Reconciling biodiversity conservation and food security: Scientific challenges for a new agriculture. Curr. Opin. Environ. Sustain. 2010, 2, 34-42. [CrossRef]

7. Sollenberger, L.E.; Kohmann, M.M.; Dubeux, J.C.B., Jr.; Silveira, M.L. Grassland management affects delivery of regulating and supporting ecosystem services. Crop Sci. 2019, 59, 441-459. [CrossRef]

8. Boone, R.B.; Conant, R.T.; Sircely, J.; Thornton, P.K.; Herrero, M. Climate change impacts on selected global rangeland ecosystem services. Glob. Chang. Biol. 2018, 24, 1382-1393. [CrossRef]

9. Hatfield, J.L.; Boote, K.J.; Kimball, B.A.; Ziska, L.H.; Izaurralde, R.C.; Ort, D.; Thomson, A.M.; Wolfe, D. Climate impacts on agriculture: Implications for crop production. Agron. J. 2011, 103, 351-370. [CrossRef]

10. Izaurralde, R.C.; Thomson, A.M.; Morgan, J.A.; Fay, P.A.; Polley, H.W.; Hatfield, J.L. Climate impacts on agriculture: Implications for forage and rangeland production. Agron. J. 2011, 103, 371-381. [CrossRef]

11. Steiner, J.L.; Wagle, P.; Gowda, P. Management of water resources for grasslands. In Improving Grassland and Pasture Management in Agriculture; Marshall, A., Collins, R., Eds.; Burleigh Dodds Science Publishing: Cambridge, UK, 2017; pp. 265-282.

12. Samson, F.B.; Knopf, F.L.; Ostlie, W.R. Great Plains ecosystems: Past, present, and future. Wildl. Soc. Bull. 2004, 32, 6-15. [CrossRef] 
13. Samson, F.; Knopf, F. Prairie conservation in North America. BioScience 1994, 44, 418-421. [CrossRef]

14. Conner, R.; Seidl, A.; VanTassell, L.; Wilkins, N. United States Grasslands and Related Resources: An Economic and Biological Trends Assessment. 2002. Available online: http://twri.tamu.edu/media/256592/ unitedstatesgrasslands.pdf (accessed on 25 March 2019).

15. Askins, R.; Chavez-Ramirez, F.; Dale, B.; Haas, C.; Herkert, J.; Knopf, F.; Vickery, P.D. Conservation of Grassland Birds in North America: Understanding Ecological Processes in Different Regions; The American Ornithologists' Union: Chicago, IL, USA, 2007; pp. 1-46.

16. Comer, P.J.; Hak, J.C.; Kindscher, K.; Muldavin, E.; Singhurst, J. Continent-scale landscape conservation design for temperate grasslands of the Great Plains and Chihuahuan Desert. Nat. Areas J. 2018, 38, 196-211. [CrossRef]

17. Hill, J.M.; Egan, J.F.; Stauffer, G.E.; Diefenbach, D.R. Habitat availability is a more plausible explanation than insecticide acute toxicity for US grassland bird species declines. PLoS ONE 2014, 9, e98064. [CrossRef]

18. Derner, J.D.; Smart, A.J.; Toombs, T.P.; Larsen, D.; McCulley, R.L.; Goodwin, J.; Sims, S.; Roche, L.M. Soil health as a transformation change agent for US grazinglands management. Rangel. Ecol. Manag. 2018, 71, 403-408. [CrossRef]

19. Sarkar, S. Phenology and carbon fixing: A satellite-based study over Continental USA. Int. J. Remote Sens. 2018, 39, 1-16. [CrossRef]

20. Teague, W.R. Toward restoration of ecosystem function and livelihoods on grazed agroecosystems. Crop Sci. 2015, 55, 2550-2556. [CrossRef]

21. Park, J.-Y.; Ale, S.; Teague, W.R. Simulated water quality effects of alternate grazing management practices at the ranch and watershed scales. Ecol. Model. 2017, 360, 1-13. [CrossRef]

22. Wang, J.; Xiao, X.; Qin, Y.; Doughty, R.B.; Dong, J.; Zou, Z. Characterizing the encroachment of juniper forests into sub-humid and semi-arid prairies from 1984 to 2010 using PALSAR and Landsat data. Remote Sens. Environ. 2018, 205, 166-179. [CrossRef]

23. Caterina, G.L.; Will, R.E.; Turton, D.J.; Wilson, D.S.; Zou, C.B. Water use of Juniperus virginiana trees encroached into mesic prairies in Oklahoma, USA. Ecohydrology 2014, 7, 1124-1134.

24. Qiao, L.; Zou, C.B.; Stebler, E.; Will, R.E. Woody plant encroachment reduces annual runoff and shifts runoff mechanisms in the tallgrass prairie, USA. Water Resour. Res. 2017, 53, 4838-4849. [CrossRef]

25. Acharya, B.S.; Hao, Y.; Ochsner, T.E.; Zou, C.B. Woody plant encroachment alters soil hydrological properties and reduces downward flux of water in tallgrass prairie. Plant Soil 2017, 414, 379-391. [CrossRef]

26. Zhou, Y.; Xiao, X.; Zhang, G.; Wagle, P.; Bajgain, R.; Dong, J.; Jin, C.; Basara, J.B.; Anderson, M.C.; Hain, C.; et al. Quantifying agricultural drought in tallgrass prairie region in the U.S. Southern Great Plains through analysis of a water-related vegetation index from MODIS images. Agric. For. Meteorol. 2017, 246, 111-122. [CrossRef]

27. Augustine, D.J.; Blumenthal, D.M.; Springer, T.L.; LeCain, D.R.; Gunter, S.A.; Derner, J.D. Elevated $\mathrm{CO}_{2}$ induces substantial and persistent declines in forage quality irrespective of warming in mixed grass prairie. Ecol. Appl. 2018, 28, 721-735. [CrossRef]

28. Riitters, K.H.; Wickham, J.D. How far to the nearest road? Front. Ecol. Environ. 2003, 1, 125-129. [CrossRef]

29. Lal, R. Global food security and nexus thinking. J. Soil Water Conserv. 2016, 71, 85A-90A. [CrossRef]

30. Holechek, J.L.; Pieper, R.D.; Herbel, C.H. Range Management Principles and Practices; Chapter 8 Considerations Concerning Stocking Rate; Pearson, Prentice Hall: Upper Saddle River, NJ, USA, 2004; pp. 216-260.

31. Savory, A.; Butterfield, J. Holistic Management: A New Framework for Decision Making, 2nd ed.; Island Press: Washington, DC, USA, 1999; 644p.

32. Teague, W.R.; Apfelbaum, S.; Lall, R.; Kreuter, U.P.; Rowntree, J.; Davies, C.A.; Concer, R.; Rasmussen, M.; Hatield, J.; Wang, T.; et al. The role of ruminants in reducing agriculture's carbon footprint in North America. J. Soil Water Conserv. 2016, 71, 156-164. [CrossRef]

33. Briske, D.D.; Derner, J.D.; Brown, J.R.; Fuhlendorf, S.D.; Teague, W.R.; Havstad, K.M.; Gillen, R.L.; Ash, A.J.; Willms, W.D. Rotational grazing on rangelands: Reconciliation of perception and experimental evidence. Rangel. Ecol. Manag. 2008, 61,3-17. [CrossRef]

34. Briske, D.D.; Sayre, N.F.; Huntsinger, L.; Fernandez-Gimenez, M.; Budd, B.; Derner, J.D. Origin, persistence, and resolution of the rotational grazing debate: Integrating human dimension into rangeland research. Rangel. Ecol. Manag. 2011, 64, 325-334. [CrossRef] 
35. Derner, J.; Briske, D.; Boutton, T. Does grazing mediate soil carbon and nitrogen accumulation beneath C4, perennial grasses along an environmental gradient? Plant Soil 1997, 191, 147-156. [CrossRef]

36. Fuhlendorf, S.D.; Zhang, H.; Tunnell, T.; Engle, D.M.; Cross, A.F. Effects of grazing on restoration of southern mixed prairie soils. Restor. Ecol. 2002, 10, 401-407. [CrossRef]

37. Henderson, D.C.; Ellert, B.H.; Naeth, M.A. Grazing and soil carbon along a gradient of Alberta rangelands. J. Range Manag. 2004, 57, 402-410. [CrossRef]

38. Owensby, C.E.; Ham, J.M.; Auen, L.M. Fluxes of $\mathrm{CO}_{2}$ from grazed and ungrazed tallgrass prairie. Rangel. Ecol. Manag. 2006, 59, 111-127. [CrossRef]

39. Follett, R.F.; Reed, D.A. Soil carbon sequestration in grazing lands: Societal benefits and policy implications. Rangel. Ecol. Manag. 2010, 63, 4-15. [CrossRef]

40. Northup, B.K.; Daniel, J.A. Distribution of soil bulk density and organic matter along an elevation gradient in central Oklahoma. Trans. ASABE 2010, 53, 1749-1757. [CrossRef]

41. Franzluebbers, A.; Stuedemann, J. Bermudagrass management in the Southern Piedmont USA: VII. Soil-profile organic carbon and total nitrogen. Soil Sci. Soc. Am. J. 2005, 69, 1455-1462. [CrossRef]

42. Northup, B.K.; Starks, P.J.; Turner, K.E. Stocking methods and soil macronutrient distributions in southern tallgrass paddocks: Are there linkages? Agronomy 2019, 9, 281. [CrossRef]

43. Northup, B.K.; Starks, P.J.; Turner, K.E. Soil macronutrient responses in diverse landscapes of southern tallgrass to two stocking methods. Agronomy 2019, 9, 329. [CrossRef]

44. Starks, P.J.; Steiner, J.L.; Neel, J.P.S.; Turner, K.E.; Northup, B.K.; Gowda, P.H.; Brown, M.A. Assessment of the standardized precipitation and evaporation index (SPEI) as a potential management tool for grasslands. Agronomy 2019, 9, 235. [CrossRef]

45. Spiegal, S.; Bestelmeyer, B.T.; Archer, D.W.; Augustine, D.J.; Boughton, E.H.; Boughton, R.K.; Cavigelli, M.A.; Clark, P.E.; Derner, J.D.; Duncan, E.W.; et al. Evaluating strategies for sustainable intensification of US agriculture through the Long-Term Agroecosystem Research network. Environ. Res. Lett. 2018, 13, 034031. [CrossRef]

46. Kleinman, P.J.A.; Spiegal, S.; Rigby, J.R.; Goslee, S.C.; Baker, J.M.; Bestelmeyer, B.T.; Boughton, R.K.; Bryant, R.B.; Cavigelli, M.A.; Derner, J.D.; et al. Advancing the Sustainability of US Agriculture through Long-Term Research. J. Environ. Qual. 2018, 47, 1412-1425. [CrossRef]

47. Garbrecht, J.D.; Rossel, F. Decade-scale precipitation increase in the Great Plains at the end of the 20th century. J. Hydrol. Eng. 2002, 7, 64-75. [CrossRef]

48. Garbrecht, J.D.; Van Liew, M.; Brown, G.O. Trends in precipitation, streamflow and ET in the Great Plains. J. Hydrol. Eng. 2004, 9, 360-367. [CrossRef]

49. Garbrecht, J.D.; Zhang, X.C.; Steiner, J.L. Climate change and observed climate trends in the Fort Cobb Experimental Watershed. J. Environ. Qual. 2014, 43, 1319-1327. [CrossRef]

50. Kunkel, K.E.; Karl, T.R.; Brooks, H.; Kossin, J.; Lawrimore, J.H.; Arndt, D.; Bosart, L.; Changnon, D.; Cutter, S.L.; Doesken, N.; et al. Monitoring and understanding trends in extreme storms: State of Knowledge. Bull. Am. Meteorol. Soc. 2013, 94, 499-514. [CrossRef]

51. Christian, J.; Christian, K.; Basara, J. Drought and pluvial dipole events within the Great Plains of the United States. J. Appl. Meteorol. Climatol. 2015, 54, 1886-1898. [CrossRef]

52. Oklahoma Climatological Survey. Climate of Oklahoma. Available online: https://limate.ok.gov/index.php/ site/page/climate_of_oklahoma (accessed on 28 March 2019).

53. Omernik, J.M.; Griffith, G.E. Ecoregions of the conterminous United States: Evolution of a hierarchical spatial framework. Environ. Manag. 2014, 54, 1249-1266. [CrossRef] [PubMed]

54. Day, P.R. Particle fractionation and particle-size analysis. In Methods of Soil Analysis; Black, C.A., Ed.; Part I. Agronomy Monograph 9; American Society of Agronomy: Madison, WI, USA; Soil Science Society of America: Madison, WI, USA, 1965; pp. 545-567.

55. Franzluebbers, A.J.; Starks, P.J.; Steiner, P.J. Conservation of soil organic carbon and nitrogen fractions in a tallgrass prairie in Oklahoma. Agronomy 2019, 9, 204. [CrossRef]

56. FASS. Guide for Care and Use of Agricultural Animals in Research and Teaching, 3rd ed.; Federation of Animal Science Societies: Champaign, IL, USA, 2010.

57. Coleman, S.W.; Gunter, S.A.; Sprinkle, J.E.; Neel, J.P. BEEF CATTLE SYMPOSIUM: Difficulties Associated with Predicting Forage Intake by Grazing Beef Cows. J. Anim. Sci. 2014, 92, 2775-2784. [CrossRef] 
58. Ma, S.; Zhou, Y.; Gowda, P.H.; Chen, L.; Starks, P.J.; Steiner, J.L.; Neel, J.P.S. Evaluating the impacts of continuous and rotational grazing on tallgrass prairie landscape using high-spatial-resolution imagery. Agronomy 2019, 9, 238. [CrossRef]

59. Buxton, D.R. Quality-related characteristics of forages as influenced by plant environment and agronomic factors. Anim. Feed Sci. Technol. 1996, 59, 37-49. [CrossRef]

60. Zhou, Y.; Gowda, P.H.; Wagle, P.; Ma, S.; Neel, J.P.S.; Kakani, V.G.; Steiner, J.L. Climate effects on tallgrass prairie responses to continuous and rotational grazing. Agronomy 2019, 9, 219. [CrossRef]

61. Venter, Z.S.; Hawkins, H.; Cramer, M.D. Cattle don't care: Animal behaviour is similar regardless of grazing management in grasslands. Agric. Ecosyst. Environ. 2018, 272, 175-187. [CrossRef]

62. Cummings, D.C.; Fuhlendorf, S.D.; Engle, D.M. Is altering grazing selectivity of invasive forage species with patch burning more effective than herbicide treatments? Rangel. Ecol. Manag. 2007, 60, 253-260. [CrossRef]

(C) 2019 by the authors. Licensee MDPI, Basel, Switzerland. This article is an open access article distributed under the terms and conditions of the Creative Commons Attribution (CC BY) license (http://creativecommons.org/licenses/by/4.0/). 